\title{
Effects of palmitic acid on milk production and insulin sensitivity in mid-lactation dairy cows
}

Alice Treffry Mathews

Follow this and additional works at: https://researchrepository.wvu.edu/etd

\section{Recommended Citation}

Mathews, Alice Treffry, "Effects of palmitic acid on milk production and insulin sensitivity in mid-lactation dairy cows" (2016). Graduate Theses, Dissertations, and Problem Reports. 6176.

https://researchrepository.wvu.edu/etd/6176

This Thesis is protected by copyright and/or related rights. It has been brought to you by the The Research Repository @ WVU with permission from the rights-holder(s). You are free to use this Thesis in any way that is permitted by the copyright and related rights legislation that applies to your use. For other uses you must obtain permission from the rights-holder(s) directly, unless additional rights are indicated by a Creative Commons license in the record and/ or on the work itself. This Thesis has been accepted for inclusion in WVU Graduate Theses, Dissertations, and Problem Reports collection by an authorized administrator of The Research Repository @ WVU. For more information, please contact researchrepository@mail.wvu.edu. 
EFFECTS OF PALMITIC ACID ON MILK PRODUCTION AND INSULIN SENSITIVITY IN MID-LACTATION DAIRY COWS.

ALICE TREFFRY MATHEWS

\author{
THESIS \\ Submitted \\ to the Davis College \\ at West Virginia University
}

In partial fulfillment of the requirements for the degree of

Master of Science in

Nutrition and Food Sciences

Joseph W. McFadden, Ph.D.

K. Marie Krause, Ph.D.

Janet C. Tou, Ph.D

Division of Animal and Nutritional Sciences

Morgantown, West Virginia

2016

Keywords: dairy cow, insulin resistance, lactation, palmitic acid

Copyright 2016 Alice Mathews 


\title{
ABSTRACT \\ EFFECTS OF PALMITIC ACID ON MILK PRODUCTION AND INSULIN SENSITIVITY IN MID-LACTATION DAIRY COWS.
}

\begin{abstract}
Alice Mathews
This masters of science research evaluates the effects of palmitic acid (C16:0) supplementation on milk production and insulin sensitivity in mid-lactation dairy cows. The ability of saturated fatty acids (SFA) to enhance milk yield in dairy cows may be due to shifts in glucose utilization caused by reduced insulin sensitivity in adipose tissue. Our objective was to evaluate the effects of palmitic acid (C16:0) on milk production and insulin sensitivity in cows. Twenty multiparous mid-lactation Holstein cows were enrolled in a study consisting of a $5 \mathrm{~d}$ covariate, $49 \mathrm{~d}$ treatment, and $14 \mathrm{~d}$ post-treatment period. All cows received a common sorghum silage-based diet and were randomly assigned to a diet containing no supplemental fat (control; $\mathrm{n}$ $=10 ; 138 \pm 45$ DIM) or C16:0 at $4 \%$ of ration DM (PALM; 98\% C16:0; $\mathrm{n}=10 ; 136 \pm 44$ DIM). Blood and milk were collected at routine intervals. Intravenous glucose tolerance tests (300 $\mathrm{mg} / \mathrm{kg}$ of body weight (BW); GTT) were performed at $\mathrm{d}-1,21$, and 49 relative to start of treatment. Data were analyzed as repeated measures using a mixed model with fixed effects of treatment and time, and milk yield served as a covariate. PALM increased milk yield, energycorrected milk (ECM), and milk fat yield at wk 3, responses that were maintained at wk 7. Furthermore, PALM increased protein yield at wk 7. Changes in milk production occurred in parallel with enhanced energy intake and improved feed efficiency (ECM/dry matter intake). Enhanced milk fat yield during PALM treatment was due to increased C16:0 and C16:1 incorporation. Supplementation of PALM had no effect on concentration of milk components, BW, or body condition score. Two weeks post-treatment, ECM and milk fat yield remained elevated in PALM-fed cows while yields of milk were similar between treatments. The concentration of non-esterified fatty acids (NEFA) in plasma increased by d 4, 6, and 8 of PALM treatment, a response not observed thereafter. Although PALM supplementation did not modify insulin, glucose, or triacylglycerol levels in plasma, total cholesterol in plasma was elevated by wk 3. Estimated insulin sensitivity was lower during the first week of PALM treatment; however, glucose disposal following GTT was not modified. In contrast, PALM feeding reduced glucose-stimulated NEFA disappearance by wk 7. Results demonstrate that increasing dietary energy from C16:0 for a 7 wk duration improves milk yield and milk composition without modifying systemic glucose tolerance. Reduced glucose-stimulated NEFA disappearance with PALM supplementation and elevated circulating NEFA may reflect changes in adipose tissue insulin sensitivity.
\end{abstract}


This thesis is dedicated to my mother, father, sister, and family. 


\section{ACKNOWLEDGEMENTS}

I would like to thank Dr. Joseph McFadden for giving me the opportunity to conduct research in his laboratory, and his advisory throughout my Masters program at West Virginia University. The opportunities I have had at the McFadden lab are incalculable, and Dr. McFadden's guidance was crucial in developing my skills as a scientific researcher, writer, and communicator.

Secondly, I thank the members of my graduate advisory committee, Dr. Marie Krause and Dr. Janet Tou. Their advisory both within the classroom and in separate meetings has been vital, not only in learning basic scientific concepts, but in giving insight into making decisions toward my education and future.

Additionally, I would like to thank all the members of the McFadden lab: Sina Saed Samii, Yu Zang, Amanda Davis, Zachary Phipps, and Eduardo Rico. Their friendship, support, and teamwork has supported me throughout my time at WVU. Each member taught me skills and expertise that I will take with me in my next endeavor.

I also acknowledge the staff members at WVU animal science farm for their care of our animals, as well as technical support during experiments. A special thanks to Will McClung, Fred Roe, George Bolyard, Greg Kurilla, and Curtis Swiantek, who were helpful in several ways.

Finally, to my entire family for their support, and especially to my mother, father, and sister, who encouraged me throughout my Masters. 


\section{TABLE OF CONTENTS}

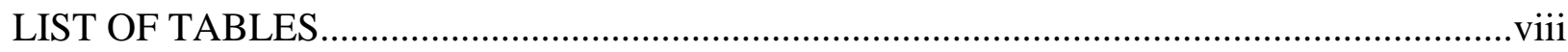

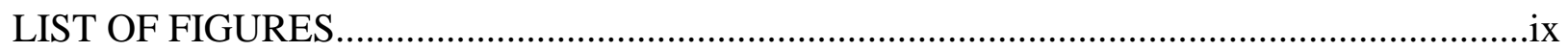

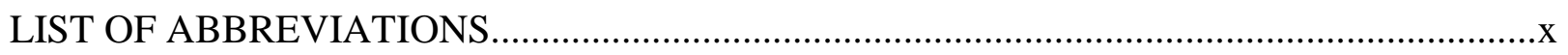

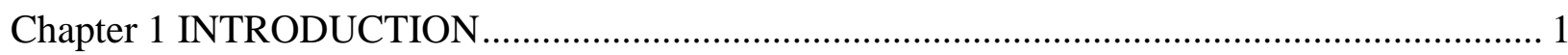

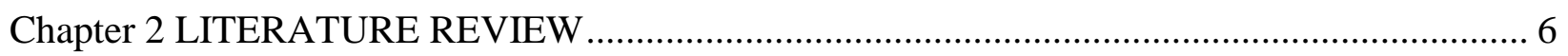

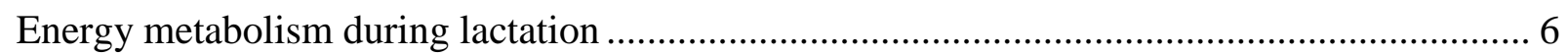

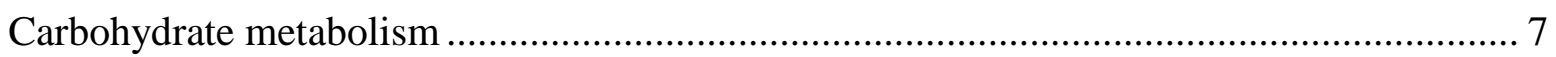

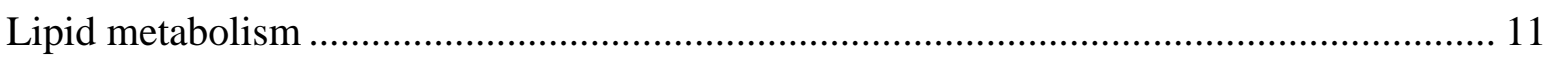

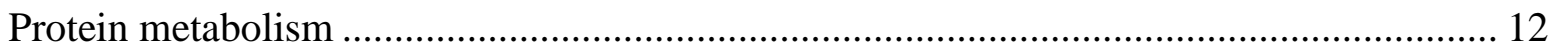

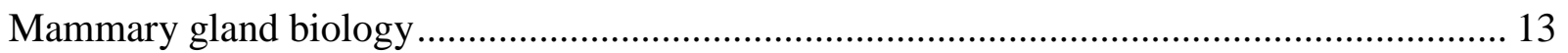

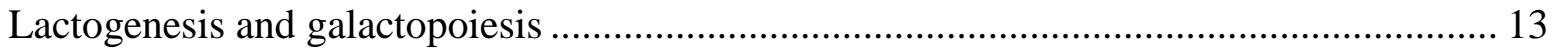

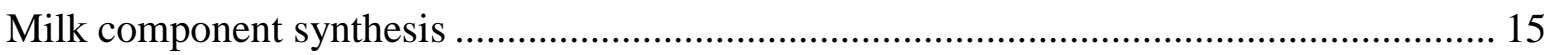

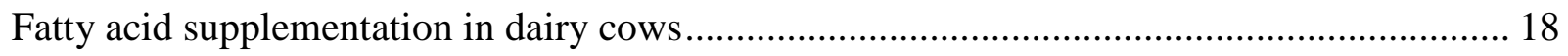

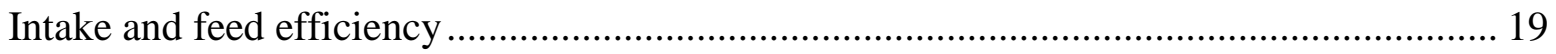

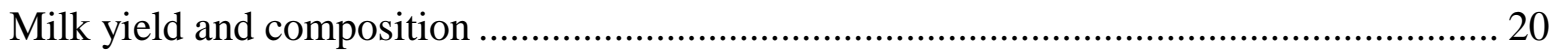

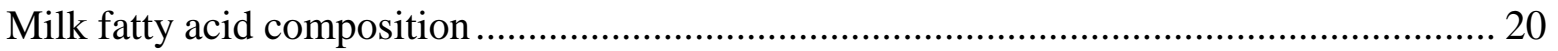

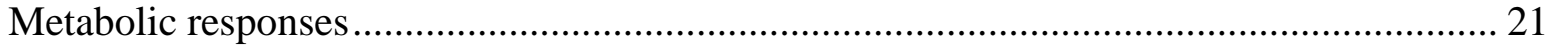

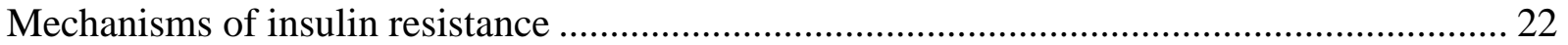

Chapter 3 INCREASING PALMITIC ACID INTAKE ENHANCES MILK PRODUCTION AND PREVENTS GLUCOSE-STIMULATED NEFA DISAPPEARANCE WITHOUT MODIFYING SYSTEMIC GLUCOSE TOLERANCE IN MID-LACTATION DAIRY COWS

Materials and methods 33 


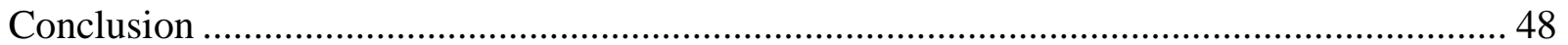




\section{LIST OF TABLES}

Table 1. Ingredients and nutrient composition (\% of DM unless otherwise noted) of experimental diets supplemented with palmitic acid (PALM; C16:0) and control (no added fat)...... 49

Table 2. Production variables during covariate period. ..................................................... 50

Table 3. Production responses to palmitic acid supplementation. ........................................... 51

Table 4. Milk fatty acid yields (g/d) of cows fed treatment diets......................................... 51

Table 5. Milk fatty acid concentration $(\mathrm{g} / 100 \mathrm{~g})$ of cows fed treatment diets........................... 54

Table 6. Milk fatty acid yield (g/d) and concentration (g/100 g) during covariate period. .......... 56

Table 7. Area under the curve for glucose and NEFA during glucose tolerance testing............. 57 


\section{LIST OF FIGURES}

Figure 1. Palmitic acid supplementation increases milk yield and net energy intake.

Figure 2. Palmitic acid supplementation acutely increases circulating NEFA and decreases estimated insulin sensitivity.

Figure 3. Feeding cows C16:0 increases circulating cholesterol without modifying circulating triacylglycerol . 61

Figure 4. Palmitic acid feeding does not modify glucose tolerance but reduces glucosestimulated NEFA disappearance. 


\section{LIST OF ABBREVIATIONS}

\begin{tabular}{ll} 
AA & Amino acid \\
ACC & Acetyl-CoA carboxylase \\
ATP & Adenosine triphosphate \\
CoA & Coenzyme A \\
BCS & Body condition score \\
BW & Body weight \\
BHBA & Beta-hydroxybutyric acid \\
cAMP & Cyclic adenosine monophosphate \\
CCK & Cholecystokinin \\
DAG & Diacylglycerol \\
DMI & Dry matter intake \\
ECM & Energy-corrected milk \\
FCM & Fat-corrected milk \\
FIL & Feedback inhibitor of lactation \\
GTT & Glucose tolerance test \\
GLUT & Glucose transporter \\
GPAT & Glycerol 3-phosphate acyltransferase \\
IGF-1 & Inuslin-like growth factor-1 \\
LCFA & Long-chain fatty acid(s) \\
LPL & Lipoprotein lipase \\
mTOR & Mammalian target of rapamycin \\
mRNA & Messenger RNA \\
MUFA & Monounsaturated fatty acid(s) \\
MUN & Milk urea nitrogen \\
\hline
\end{tabular}


NADPH Nicotinamide adenine dinucleotide phosphate

NEB Negative energy balance

NEFA Non-esterified fatty acid(s)

OAA Oxaloacetate

PEPCK Phosphoenolpyruvate

PUFA Polyunsaturated fatty acid(s)

PPP Pentose phosphate pathway

RDP Rumen degradable protein

RUP Rumen undegradable protein

SCFA Short-chain fatty acid(s)

SGLT Sodium-dependent glucose transporter

SFA Saturated fatty acid(s)

TAG Triacylglycerol

UFA Unsaturated fatty acid(s)

VFA Volatile fatty acids 


\section{Chapter 1}

\section{INTRODUCTION}

The onset of lactation involves homeorhetic adaptations in energy metabolism to divert nutrients to the mammary gland to support milk production (Bauman and Currie, 1980;

Drackley, 1999). Specifically, the early lactation cow will develop insulin resistance in adipose and skeletal muscle tissues (Bell and Bauman, 1997). As a consequence, glucose is partitioned away from these tissues and toward the mammary gland to support lactose synthesis, the major osmotic regulator of milk volume (Walstra, 2013). Because insulin is an antilipolytic hormone, insulin resistance enhances adipose tissue lipolysis to partition NEFA toward peripheral tissues for $\beta$-oxidation and the mammary gland for re-esterification (Drackley et al., 2010). Although insulin resistance does not appear to develop in liver (Zachut et al., 2013), the peripartal dairy cow will experience an increase in hepatic gluconeogenesis to maintain homeostasis (Drackley et al., 2010). Collectively, these coordinated shifts in metabolism provide the mammary gland with necessary energy during the onset of lactation when energy intake is insufficient to meet metabolic demand. Beyond peak milk yield, insulin sensitivity in the cow increases, adipose tissue lipogenesis is favored (Mashek et al., 2001), and nutrients are partitioned toward the growing fetus (Bauman and Currie, 1980). As a consequence, milk yield gradually declines as the cow advances toward late lactation (McNamara and Hillers, 1986).

As a means to enhance milk production during mid- and late-lactation, dairy producers supplement dairy cow rations with high-energy fat sources that can vary in saturation and acylchain length (Drackley, 2004). Unsaturated fatty acid (UFA) supplements are toxic to many fiber-fermenting rumen microbes because they disrupt membrane function (Drackley, 2004; Jenkins, 1993). Therefore, UFA undergo ruminal biohydrogenation to become saturated 
(Drackley, 2004). Biohydrogenation can decrease dry matter intake (DMI) (Kirovski et al., 2015), inhibit milk fat synthesis, and decrease milk production (Drackley, 2004). In contrast, saturated fatty acid (SFA) supplements can bypass rumen biohydrogenation are absorbed by the intestinal epithelium intact, and the production responses to SFA supplementation are favorable (Drackley, 2004). For instance, increasing SFA intake in dairy cows can increase feed efficiency, milk yield, and milk fat yield (Wang et al., 2010), while having little effect on DMI (Allen, 2000; Loften et al., 2014). Furthermore, production responses are dependent upon chain length of the SFA. Previous research shows that when lactating cows are supplemented with either stearic acid (C18:0) or C16:0, milk and fat yield are significantly higher in the C16:0-fed cows (Rico et al., 2014b). Although production responses have been characterized, the mechanism through which C16:0 increases in milk fat yield remains unknown.

Though SFA feeding appears to alter metabolic status, few studies have made this the focus of their research, instead concentrating on production responses (Piantoni et al., 2013; Rico et al., 2014b). Available data on metabolism indicates that in addition to increased milk and fat yield observed in response to SFA, dairy cows exhibit elevated circulating NEFA (Piantoni et al., 2013; Rico et al., 2014b), insulin (Piantoni et al., 2013) and glucose (Rico et al., 2014b). Furthermore, there is a relationship between concentration of circulating NEFA and insulin resistance in ruminants (De Koster and Opsomer, 2013). Recently, Pires et al. (2007) discovered that the infusion of tallow to dry cows induces insulin resistance and decreases glucose tolerance. However, whether elevations in circulating SFA play a role in causing insulin resistance in midlactation dairy cows remains unclear.

In contrast to ruminants, the relationship between SFA intake and the development of insulin resistance is well established in monogastrics (Larsen and Tennagels, 2014). Monogastric 
insulin resistance is partly due to C16:0-stimulated increases in de novo synthesis of sphingolipid ceramide, which directly antagonize the insulin signaling pathway in muscle, adipose, and liver tissues (Funaki, 2009; DeFronzo, 2010; Larsen and Tennagels, 2014). This occurs through blocking phosphorylation of protein kinase B (Akt) in the insulin signaling pathway, preventing glucose transporter 4 (GLUT4) translocation to the plasma membrane (Larsen and Tennagels, 2014). Current evidence suggests mechanistic similarities in ruminants and monogastrics in SFA-induced insulin resistance. Because the majority of research surrounding C16:0 supplementation emphasizes production responses, giving minimal attention to changes in metabolism, the focus of this thesis is to evaluate the effects of C16:0 feeding on changes in milk yield and components, and how these are associated with insulin sensitivity in mid-lactation dairy cows.

\section{Literature Cited}

Allen, M. S. 2000. Effects of diet on short-term regulation of feed intake by lactating dairy cattle. J. Dairy Sci. 83:1598-1624.

Bauman, D. E. and W. B. Currie. 1980. Partitioning of nutrients during pregnancy and lactation: A review of mechanisms involving homeostasis and homeorhesis. J. Dairy Sci. 63:15141529.

Bell, A. W. and D. E. Bauman. 1997. Adaptations of glucose metabolism during pregnancy and lactation. J. Mammary Gland Biol. Neoplasia 2:265-278.

Kirovski, D. B. B., M. Katic, R. Markovic, and D. Sefer. 2015. Milk yield and composition, body condition, rumen characteristics, and blood metabolites of dairy cows fed diet supplemented with palm oil. Chem. Biol. Technol. Agric. 2:2-5.

De Koster, J. D. and G. Opsomer. 2013. Insulin resistance in dairy cows. Vet. Clin. N. Am-Food A. 29:299-322.

Defronzo, R. A. 2010. Insulin resistance, lipotoxicity, type 2 diabetes and atherosclerosis: The missing links. The claude bernard lecture 2009. Diabetologia 53:1270-1287. 
Drackley, J. K. 1999. Biology of dairy cows during the transition period: The final frontier? J. Dairy Sci. 82:2259-2273.

Drackley, J. K. 2004. Overview of fat digestion and metabolism in dairy cows.

Drackley, J. K., H. M. Dann, G. N. Douglas, N. A. Janovick Guretzky, N. B. Litherland, J. P. Underwood, and J. J. Loor. 2005. Physiological and pathological adaptations in dairy cows that may increase susceptibility to periparturient diseases and disorders. Ital. J. Anim. Sci. 4:323-344.

Funaki, M. 2009. Saturated fatty acids and insulin resistance. J. Med. Invest. 56:88-92.

Jenkins, T. C. 1993. Lipid metabolism in the rumen. J. Dairy Sci. 76:3851-3863.

Larsen, P. J. and N. Tennagels. 2014. On ceramides, other sphingolipids and impaired glucose homeostasis. Mol. Metab. 3:252-260.

Loften, J. R., J. G. Linn, J. K. Drackley, T. C. Jenkins, C. G. Soderholm, and A. F. Kertz. 2014. Invited review: Palmitic and stearic acid metabolism in lactating dairy cows. J. Dairy Sci. 97:4661-4674.

Mashek, D. G., K. L. Ingvartsen, J. B. Andersen, M. Vestergaard, and T. Larsen. 2001. Effects of a four-day hyperinsulinemic-euglycemic clamp in early and mid-lactation dairy cows on plasma concentrations of metabolites, hormones, and binding proteins. Domest. Anim. Endocrinol. 21:169-185.

Mcnamara, J. P. and J. K. Hillers. 1986. Adaptations in lipid metabolism of bovine adipose tissue in lactogenesis and lactation J. Lipid Res. 27:150-157.

Mosley, S. A., E. E. Mosley, B. Hatch, J. I. Szasz, A. Corato, N. Zacharias, D. Howes, and M. A. Mcguire. 2007. Effect of varying levels of fatty acids from palm oil on feed intake and milk production in holstein cows. J. Dairy Sci. 90:987-993.

Piantoni, P., A. L. Lock, and M. S. Allen. 2013. Palmitic acid increased yields of milk and milk fat and nutrient digestibility across production level of lactating cows. J. Dairy Sci. 96:7143-7154.

Pires, J. A., A. H. Souza, and R. R. Grummer. 2007. Induction of hyperlipidemia by intravenous infusion of tallow emulsion causes insulin resistance in holstein cows. J. Dairy Sci. 90:2735-2744.

Rico, J. E., M. S. Allen, and A. L. Lock. 2014. Compared with stearic acid, palmitic acid increased the yield of milk fat and improved feed efficiency across production level of cows. J. Dairy Sci. 97:1057-1066. 
Rico, J. E., V. V. R. Bandaru, J. M. Dorskind, N. J. Haughey, and J. W. Mcfadden. 2015. Plasma ceramides are elevated in overweight holstein dairy cows experiencing greater lipolysis and insulin resistance during the transition from late pregnancy to early lactation. J. Dairy Sci. 98:7757-7770.

Walstra, P. 2013. Dairy technology: Principles of milk properties and processes. CRC Press.

Wang, J. P., D. P. Bu, J. Q. Wang, X. K. Huo, T. J. Guo, H. Y. Wei, L. Y. Zhou, R. R. Rastani, L. H. Baumgard, and F. D. Li. 2010. Effect of saturated fatty acid supplementation on production and metabolism indices in heat-stressed mid-lactation dairy cows. J. Dairy Sci. 93:4121-4127.

Zachut, M., H. Honig, S. Striem, Y. Zick, S. Boura-Halfon, and U. Moallem. 2013. Periparturient dairy cows do not exhibit hepatic insulin resistance, yet adipose-specific insulin resistance occurs in cows prone to high weight loss. J. Dairy Sci. 96:5656-5669. 


\section{Chapter 2}

\section{LITERATURE REVIEW}

\section{Energy metabolism during lactation}

Early lactation dairy cattle experience a suppression in appetite and increased energy demand to support the production of milk (Bauman and Currie, 1980; Bell, 1995; Bell and Bauman, 1997). To meet the metabolic demand of lactation, the dairy cow must develop homeorhetic adaptations to partition nutrients to the mammary gland (Bauman and Currie, 1980; Bell, 1995). The mammary gland requires up to $80 \%$ of the glucose turnover in the cow during early lactation (Bauman and Currie, 1980). Because of the increase in mammary gland glucose uptake, the early lactation cow will experience an increase in gluconeogenesis and glycogenolysis as an attempt to maintain glucose homeostasis (Bauman and Currie, 1980). Furthermore, the early lactation cow experiencing negative energy balance (NEB) will mobilize NEFA from adipose tissue triacylglycerol (TAG) and amino acids (AA) from skeletal muscle protein (Bauman and Currie, 1980). To facilitate nutrient partitioning to the mammary gland, adipose and skeletal muscle tissues will develop insulin resistance during early lactation (Bell and Bauman, 1997). The mammary gland, which is unresponsive to insulin, will utilize glucose, NEFA, and AA to synthesize milk lactose, TAG, and protein, respectively (Bauman and Currie, 1980). Beyond peak milk yield, the mid-lactation dairy cow will experience a gradual decline in milk production with the restoration of positive energy balance (McNamara and Hillers, 1986). Occurring in parallel, nutrient partitioning will be diverted away from the mammary gland and toward the growing fetus (Bauman and Currie, 1980). Furthermore, insulin sensitivity improves to favor adipose tissue lipogenesis and skeletal muscle protein accretion (McNamara and Hillers, 1986). 


\section{Carbohydrate metabolism}

In a typical commercial dairy ration, sources of carbohydrates are in the form of nonstructural or structural carbohydrates (NRC, 2001). Nonstructural carbohydrates include sugars and starch, and are highly digestible compared with structural carbohydrates cellulose, hemicellulose, and lignin (Nafikov and Beitz, 2007). Nutritionists evaluate dietary structural carbohydrate availability by measuring neutral detergent fiber (NDF; cellulose, hemicellulose, and lignin) as well as acid detergent fiber (ADF; lignin and cellulose) (Nafikov and Beitz, 2007). The recommended NDF concentration for early- and mid-lactation dairy cows is approximately $30 \%$ of diet dry matter, with at least $75 \%$ of that NDF being from forage (NRC, 2001). Additionally, the concentration of nonfermentable carbohydrates should be $35-38 \%$ of the diet (NRC, 2001). Formulating dairy cow rations to have a correct percentage of fiber and carbohydrates is critical for a steady rumen $\mathrm{pH}$ to reduce the risk of rumen acidosis and maintain the rate of volatile fatty acid (VFA) absorption (NRC, 2001).

The availability of dietary structural and nonstructural carbohydrates can influence microbial fermentation and VFA production. Volatile fatty acids are short chain fatty acids (SCFA) produced by rumen microbes that serve as essential energy sources for the ruminant animal (Bergman, 1990; Nafikov and Beitz, 2007). The primary rumen-derived VFA include acetate (2C), propionate (3C), and butyrate (4C) (Bergman, 1990; van Houtert, 1993). Upon entry into the small intestine, VFA are absorbed through the intestinal epithelium and enter hepatic portal circulation (Bergman, 1990). Acetate is a source of energy due to its contribution to the citric acid cycle, and also a major contributor of acetyl-coenzyme A (CoA) for lipid synthesis in tissues such as adipose and mammary gland (Armentano, 1992). Additionally, butyrate is a major carbon supplier for adipose tissue and mammary gland lipogenesis (Bergman, 
1990), and propionate is a primary contributor to hepatic gluconeogenesis (Nafikov and Beitz, 2007). Diet affects the profile of VFA in the rumen. Intake of rich grasses increases acetate production, forage and concentrate increases butyrate, and starch and cereal grain intake elevates propionate production. Furthermore, UFA supplements can affect VFA production due to toxicity to fiber-fermenting microbes (Jenkins, 1993). Unsaturated FA partition lipids into the microbial cell membrane, disrupting membrane cell function and expression of hydrolytic enzymes (Jenkins, 1993). Because of these effects, UFA undergo ruminal biohydrogenation to become SFA (Drackley, 2004). In contrast, feeding SFA has little effect on VFA production, and are directly absorbed into the intestinal epithelium and can be utilized for energy.

Dairy cows cannot meet their demands for glucose through diet alone because ruminant absorption of glucose is minimal (Amaral et al., 1990). To meet the homeostatic demands for circulating glucose, the dairy cow will continually rely on gluconeogenesis (Drackley et al., 2001). The dairy cow synthesizes glucose in liver and kidneys; however, hepatic gluconeogenesis contributes approximately $90 \%$ of the total glucose requirement for the animal (Amaral et al., 1990). For instance, a dairy cow that produces $90 \mathrm{~kg} / \mathrm{d}$ of milk requires $7.4 \mathrm{~kg} / \mathrm{d}$ of glucose, with $6.6 \mathrm{~kg}$ of glucose derived from gluconeogenesis (Amaral et al., 1990). To meet the metabolic demand, dairy cows require glucose precursors such as propionate, lactate, alanine and glycerol (Drackley et al., 2001; Aschenbach et al., 2010).

The rumen-derived VFA propionate is considered the predominant substrate for gluconeogenesis in ruminants (Amaral et al., 1990; Aschenbach et al., 2010). Hepatic propionate metabolism involves conversion to oxaloacetate (OAA), a key point of entry for most gluconeogenic substrates into gluconeogenesis (Aschenbach et al., 2010). The OAA can either be metabolized to form glucose through phosphoenolpyruvate (PEPCK) and glucose-6- 
phosphatase, or can serve as an acetyl-CoA acceptor in the citric acid cycle to form citrate (Wiltrout and Satter, 1971; Barthel and Schmoll, 2003; Aschenbach et al., 2010). In addition to propionate, cytosolic lactate, derived from either microbial fermentation of starch or glucose catabolism by peripheral tissues, is a second precursor for OAA and subsequently gluconeogenesis (Drackley et al., 2001; Aschenbach et al., 2010). Additionally, lactate-derived glucose can be conserved through use of the Cori cycle, which recycles glucose and lactate between the liver and muscle (Baird et al., 1983). A third contributor to gluconeogenesis are the glucogenic AA alanine and glutamine, which are deaminated to yield pyruvate for gluconeogenesis (Aschenbach et al., 2010). Together, alanine and glutamine account for 40 to $60 \%$ of the glucogenic potential of all AA (Drackley et al., 2001). When the cow is in a catabolic state, the animal will mobilize NEFA and glycerol from adipose tissue (Drackley et al., 2001). As the cow adapts to lactation, glycerol can be used as a precursor for gluconeogenesis, however only 2 to $5 \%$ of total glucose comes from glycerol (Drackley et al., 2001; Aschenbach et al., 2010). Although glycerol can be used to support gluconeogenesis, fatty acids cannot due to the irreversibility of pyruvate to acetyl CoA (Tirone and Brunicardi, 2001). In addition to gluconeogenesis, the catabolic dairy cow can rely on glycogenolysis activated by adenylate cyclase during periods of elevated glucose demand (Tirone and Brunicardi, 2001). Disadvantageously, the supply and storage of glycogen is limited during early lactation (Herdt, 2000).

Main regulators of gluconeogenesis and glycogen metabolism include pancreatic insulin and glucagon (Tirone and Brunicardi, 2001). During early lactation, cows are in a catabolic state and are resistant to insulin, allowing glucagon to upregulate glucose synthesis for increased mammary uptake (Bell and Bauman, 1997; Barthel and Schmoll, 2003). Glucagon will increase 
the rate of gluconeogenesis in part by increasing intracellular cyclic adenosine monophosphate (cAMP) (Tirone and Brunicardi, 2001) and stimulating glucose-6-phosphatase and PEPCK (Barthel and Schmoll, 2003). Following peak milk yield, glucagon levels decline and insulin levels rise. As a consequence, insulin downregulates hepatic gluconeogenesis by reducing cAMP availability, and increasing glycogen storage in liver and skeletal muscle tissues (Herdt, 2000; Barthel and Schmoll, 2003).

The mechanism of cellular glucose uptake varies depending on the cell type (Lohrenz et al., 2011). Dietary-derived glucose is absorbed in the small intestine through mediation of sodium-dependent glucose transporters (SGLT) within intestinal epithelial cells, or glucose transporter (GLUT) in the apical membrane of enterocytes (Lohrenz et al., 2011; Zheng et al., 2012). In the intestine the uptake of glucose through SGLT is driven by a difference in the sodium concentration gradient. In contrast to SGLT, intestinal GLUT2 is a low-affinity, highcapacity facilitated transporter (Zheng et al., 2012). Peripheral tissue uptake of dietary and de novo synthesized glucose occurs via various GLUT isoforms in all tissues except the kidney (Tirone and Brunicardi, 2001). Five GLUT transporters have been identified, which can be sensitive or insensitive to insulin. Liver and pancreatic beta cells contain GLUT2, which is insulin independent, allowing hepatocytes and beta cells to act as glucose sensors (Tirone and Brunicardi, 2001). As glucose levels in the blood increase, the pancreatic beta cells respond by producing and secreting more insulin, and hepatocytes respond by decreasing hepatic gluconeogenesis (Tirone and Brunicardi, 2001). The bovine mammary gland contains insulininsensitive GLUT1 (Zhao et al., 1996). Muscle and adipose tissues contain GLUT4, which is an insulin-dependent transporter, meaning that adipose and muscle tissues are susceptible to insulin resistance (Zhao et al., 1996). In adipose and muscle, insulin action can increase GLUT4 
translocation to the plasma membrane upon activation of protein kinase B (Akt) (Zeng et al., 2000; Tirone and Brunicardi, 2001).

\section{Lipid metabolism}

Lipid content in the diet of a ruminant is primarily composed of TAG followed by glycolipids, phospholipids, and NEFA (Drackley, 2004). Although NEFA are not a major component of a dairy cow ration they are the main ingredient in most purified fat supplements (Drackley, 2004). Fat supplements can be either UFA or SFA, however UFA are toxic to many species of rumen microbes (Jenkins, 1993; Palmquist, 2006). Typically 90\% of dietary UFA will be hydrogenated to SFA before absorption in the small intestine (Drackley, 2004; Palmquist, 2006). Conversely, supplemental non-esterified SFA will be directly absorbed as NEFA (Palmquist, 2006), and SFA are the main type of fatty acid that reaches the small intestine for absorption (Drackley, 2004).

Within the enterocyte of the small intestine, 80-90\% of lipids are NEFA, and when no supplemental fat is added, C18:0 and C16:0 are the primary intracellular fatty acids (Drackley, 2004). In the small intestine, NEFA are incorporated into luminal micelles which are bi-layer disks that consist of bile salts and phospholipids. Micelle fatty acids are absorbed in the small intestine via the action of the emulsifier lysolecithin, an efficient emulsifier for SFA (Drackley, 2004; Palmquist, 2006). After absorption, fatty acids are esterified to glycerol forming TAG within the enterocyte. Enterocyte TAG are packaged into chylomicrons in combination with cholesterol, phospholipids, and apoproteins needed for transport (Drackley, 2004). The TAGcontaining chylomicrons are secreted into the lymph and travel to peripheral tissues where lipids are utilized through the action of lipoprotein lipase (LPL) (Drackley, 2004). The fate of fatty acids varies depending on the energy status of the cell. In the mammary gland, fatty acids can be 
formed back into TAG to support milk fat synthesis, or can be oxidized to increase ATP supply (Drackley, 2004). In adipose tissue, fatty acids can be either stored as TAG or mobilized as NEFA to be utilized by peripheral tissues (Rasmussen and Wolfe, 1999). Additionally, in the liver, fatty acids can be either stored as TAG, or oxidized for eventual ATP or ketone production. Finally, in skeletal muscle, fatty acids are oxidized and utilized as an energy source (Rasmussen and Wolfe, 1999). In ruminants, the majority of dietary fat will be utilized for TAG synthesis in the mammary gland or adipose tissue depending on the state of energy balance (Drackley, 2004).

During early lactation, the cow will experience decreased lipogenesis and enhanced lipolysis in adipose tissue, partly due to the induction of insulin resistance (Bell and Bauman, 1997). Approximately half of the mobilized NEFA are utilized for energy or ketone production or taken up by the mammary gland and re-esterified for incorporation into milk fat (Bell, 1995; Barthel and Schmoll, 2003). During mid-lactation, the anabolic dairy cow will experience a restoration in insulin sensitivity and a subsequent increase in insulin-stimulated adipose tissue lipogenesis and suppressed lipoysis (Drackley et al., 2001; Nafikov and Beitz, 2007; Laliotis et al., 2010).

\section{Protein metabolism}

Dairy cows require AA for maintenance, growth, and milk production. Necessary protein comes from the diet in the form of rumen undegradable protein (Bremmer et al., 1998) or from protein synthesized by microbes in the rumen (NRC, 2001). A high producing dairy cow should receive approximately $16 \%$ of DM as crude protein to support milk production, and lysine and methionine are critical dietary components because they are the first limiting AA (NRC, 2001). Not all crude protein provided to cows is available for intestinal absorption. Therefore, protein is further categorized into metabolizable protein which can be in the form of rumen degradable 
protein (RDP) or RUP (Bremmer et al., 1998; NRC, 2001; Hopkins and Whitlow, 2015). Both dietary RUP and RDP are required for milk protein synthesis. In the rumen, microbes breakdown RDP to release ammonia, and through the use of carbohydrates and ammonia the microbes synthesize proteins that are utilized by the animal (Hopkins and Whitlow, 2015). Excess ammonia is absorbed through the rumen and metabolized to urea in the liver (Hopkins and Whitlow, 2015). Hepatic urea can either circulate back to the rumen via saliva or be excreted in urine (Hopkins and Whitlow, 2015). Concentrations of rumen urea are measured through blood urea nitrogen or milk urea nitrogen (MUN) (Hopkins and Whitlow, 2015). Levels of MUN above $18 \mathrm{mg} / \mathrm{dL}$ indicate that a producer is either overfeeding RDP or underfeeding fermentable carbohydrates (Hopkins and Whitlow, 2015). In addition to dietary and microbial protein requirements of lactating cattle, modifications to protein metabolism occur during times of NEB (Bauman and Currie, 1980). The main homeorhetic adaptation in protein metabolism in dairy cattle is increased mobilization of AA from skeletal muscle to support hepatic gluconeogenesis and milk protein synthesis (Bauman and Currie, 1980; Bell, 1995).

\section{Mammary gland biology}

\section{Lactogenesis and galactopoiesis}

Lactogenesis is defined as the induction of milk synthesis, whereby the mammary gland alveolar cells are stimulated to secrete milk, a response that occurs after mammogenesis as parturition approaches (Neville et al., 2002). The first stage of lactogenesis ensues before parturition and involves differentiation of alveolar cells and limited secretion of milk (Husveth, 2011). Second, at parturition, the mammary gland responds to insulin, glucocorticoids, and prolactin to initiate milk synthesis (Husveth, 2011). Glucocorticoids are required for milk 
secretion, and are critical for transcription of casein and $\alpha$-lactalbumin (NRC, 1988). Near parturition, increased glucocorticoid receptor number causes elevated uptake of glucocorticoids by the mammary gland (NRC, 1988). In addition to glucocorticoids, prolactin is critical for lactogenesis (Neville et al., 2002). In the presence of insulin and glucocorticoids, prolactin initiates lactation, milk secretion and lactose and casein production (Husveth, 2011). The role of insulin in lactogenesis remains fairly elusive, although in vitro studies reveal that it may also be required for mammary cell differentiation in early lactogenesis (Howlett and Bissell, 1990).

Upon initiation of lactogenesis, prostaglandin $F_{2}$ stimulates the corpus luteum to regress causing progesterone to decrease (Husveth, 2011). Normally, progesterone suppresses lactogenesis by inhibiting the action of prolactin causing downregulation of lactose synthetase, as well as the transcription, stabilization, and translation of messenger RNA (mRNA) for milk proteins (Husveth, 2011). When progesterone levels decline, glucocorticoid levels increase stimulating prolactin secretion from the anterior pituitary gland (Husveth, 2011). After exposure to the hormones prolactin, insulin, and glucocorticoids, the mammary secretory cells differentiate and development of the endoplasmic reticulum and Golgi apparatus assists in mammary synthesis of protein, fat, and lactose for milk (Neville and Morton, 2001; Husveth, 2011).

Galactopoiesis is defined as maintenance of lactation and depends on the removal of milk from the mammary gland (Husveth, 2011). Hormones such as growth hormone, insulin-like growth factor (IGF-1), thyroid stimulating hormone, insulin, parathyroid hormone, oxytocin, as well as the feedback inhibitor of lactation (FIL) protein are all involved in maintenance of lactation (Neville et al., 2002). Growth hormone and IGF-1 maintain mammary epithelial cell number for sustained milk production (Baumrucker, 1986). In addition to growth factors maintaining cell number for milk production, oxytocin is required for milk discharge (Neville et 
al., 2002). Upon milking stimulation of the mammary teats, oxytocin is released into circulation from the neural lobe of the pituitary, and binds to receptors on myoepithelial cells surrounding the alveoli, inducing their contraction causing expulsion of milk through the ductules into the cistern (Lollivier and Marnet, 2005). Furthermore, frequent removal of milk maintains milk production by removing FIL protein which normally inhibits milk secretion through inhibiting mammary differentiation (Bar-Pelled et al., 1995). Without frequent milk removal, milk synthesis will be inhibited due in part to an accumulation of FIL (Bar-Pelled et al., 1995).

\section{Milk component synthesis}

The disaccharide lactose, composed of a glucose and a galactose unit, is the major osmotic regulator of milk volume and is consistently 5\% of milk (Mellenberger et al., 1973). Glucose is taken up by the mammary gland through GLUT1 where it is converted to UDPglucose and ultimately UDP-galactose through the action of UDP-galactose-4-epimerase. Along with a glucose unit, the newly formed galactose is used for lactose synthesis through the action of lactose synthase, composed of $\alpha$-lactalbumin and galactosyltransferase (Mellenberger et al., 1973).

In addition to lactose, protein is a major component of milk and its concentration is normally around $3.5 \%$ of milk (Bionaz et al., 2012). The main proteins in milk are caseins and whey proteins, however there are over 100 proteins in milk (Bionaz et al., 2012). The mammary gland requires up to $275 \mathrm{~g} / \mathrm{d}$ of circulating AA for milk protein synthesis, and the AA are derived from either dietary RUP, rumen microbe-derived protein, or mobilized AA from skeletal muscle tissue (Hopkins and Whitlow, 2015). Furthermore, milk protein content can be altered by availability of dietary energy (Bauman and Currie, 1980; Reynolds et al., 1994). Increased energy in the form of concentrates or fat supplements are associated with increased protein in 
milk (Reynolds et al., 1994). This is thought to be due to a greater availability of energetic precursors such as nicotinamide adenine dinucleotide phosphate (NADPH) as well as metabolizable energy because of a decrease in fat synthesis in the mammary gland during supplementation of fats (Bionaz et al., 2012). In addition to dietary energy content, availability of circulating AA affect magnitude of milk protein synthesis (Rius et al., 2010; Bionaz et al., 2012). As uptake of AA increase, flux through mammalian target of rapamycin (mTOR) in the mammary gland is enhanced, which stimulates greater utilization of AA for protein synthesis in the mammary gland (Rius et al., 2010). Additionally, insulin is thought to play an important role in milk protein synthesis. Although the mechanism remains elusive, the pattern of insulinemia during lactation closely follows the pattern of milk protein concentration (Bionaz et al., 2012).

In addition to lactose and protein, milk fat is an important, yet variable component in milk, and is usually around $4 \%$ of milk. The most predominant lipids in milk are TAG, followed by diacylglycerol (DAG) and small amounts of other lipids such as phospholipids and cholesterol (Barber et al., 1997; Månsson, 2008). There are estimated to be up to 400 different esterified fatty acids in bovine milk (Jensen, 2002), their origin being dietary, mobilized NEFA, or de novo synthesis in the mammary gland (Palmquist, 2006). When no supplemental fat is added to a dairy cow ration, approximately $50 \%$ of milk fat is derived from de novo synthesis in the mammary gland, while 50\% is taken up from circulation (Linn, 1988; Månsson, 2008; Palmquist, 2006).

Within the mammary epithelial cells, fatty acids from $\mathrm{C}_{4}$ to $\mathrm{C}_{16}$ are synthesized de novo using ruminally derived acetate and butyrate, although C16:0 is derived from either de novo synthesis or circulation (Enjalbert et al., 1998; Palmquist, 2006). The principle precursor of de novo synthesis of FA in the mammary gland is acetate. Briefly, acetate is converted to acetyl- 
CoA through acyl-CoA synthetase, and to malonyl-CoA through the rate-limiting enzyme acetylCoA carboxylase- $\alpha$ (ACC), which is activated by sterol element binding protein-1 (Nafikov and Beitz, 2007; Palmquist, 2006). The enzyme fatty acid synthase catalyzes the elongation of fatty acids and requires rumen-derived butyrate or acetate, and NADPH (Laliotis et al., 2010). In ruminants, NADPH is generated mainly through isocitrate dehydrogenase which produces NADPH through the conversion of isocitrate to $\alpha$-ketoglutarate. Additional NADPH is provided through the pentose phosphate pathway (PPP) (Laliotis et al., 2010; Nafikov and Beitz, 2007). Although citrate cleavage enzyme (ATP:citrate lyase) and malic enzyme (NADPH-malate dehydrogenase) provide additional NADPH for lipogenesis in monogastrics, activity of these enzymes are very low in ruminants, making this pathway insignificant for milk fat synthesis in dairy cows (Nafikov and Beitz, 2007). Lipogenesis of milk fatty acids ends when a thioesterase specific to the chain length produced releases the fatty acid from the enzyme complex (Palmquist, 2006).

The main mediator of mammary gland uptake of circulating chylomicron-rich TAG is LPL (Palmquist, 2006). Mammary LPL is regulated in-part by prolactin in the anterior pituitary during lactation and is synthesized in the parenchymal cells of the mammary gland and located in the capillary wall (Barber et al., 1997; Palmquist, 1996). Lipoprotein lipase hydrolyzes TAG to form NEFA, glycerol, and 2-monoacylglycerol. Around parturition LPL increases and remains elevated in the mammary gland while being down-regulated in adipose tissue (Palmquist, 2006). Although LPL is a main contributor to mammary uptake of LCFA from circulation, Barber et al. (1997) suggested that the protein fatty acid translocator may also assist with the transport of LCFA across the mammary epithelial cell membrane, and fatty acid-binding protein is involved in this process. Furthermore, fatty acid-binding protein can be transcriptionally regulated by 
LCFA through a mechanism involving peroxisomal proliferator-activated receptors (Barber et al., 1997).

Milk fatty acids must be activated to their fatty-acyl CoA ester for TAG synthesis and incorporation into milk (Palmquist, 2006). The first committed step in TAG synthesis is the acylation of glycerol-3-phosphate, and the enzyme responsible for this reaction is glycerol 3phosphate acyltransferase (GPAT) (Coleman and Lee, 2004). The action of GPAT produces phosphatidic acid which is converted to DAG, which through DAG acyltransferase is converted to TAG (Coleman and Lee, 2004; Palmquist, 2006). Once formed, TAG are incorporated into lipid droplets in the endoplasmic reticulum and are released into the lumen for incorporation into milk (Linn, 1988).

\section{Fatty acid supplementation in dairy cows}

Various forms of fats can be found in a dairy cow ration. A typical ration mainly includes TAG because these are a major source of lipid in cereal grains, oilseeds, and byproduct feeds (Drackley, 2004), and are also the major lipid in milk fat (Palmquist, 2006). Additionally, glycolipids found in forages are a source of lipid in dairy cow rations, and these are completely broken down in the rumen to release fatty acids and glycerol (Drackley, 2004). Similar to NEFA, phospholipids are a minor component of most dairy rations. However, NEFA are a major component of most fat supplements when provided to dairy cows (Drackley, 2004). Free fatty acids are not attached to a glycerol molecule, but consist of a hydrocarbon chain of variable length and saturation. In dairy cows, C16:0 and C18:0 are the most common fatty acids found within NEFA supplements (Drackley, 2004). 


\section{Intake and feed efficiency}

Although supplemental fats increase the energy density of the diet, they have been found to decrease DMI. In a review by Allen (2000), fat supplements that differ in fatty acid source, form, and type have differing effects on DMI. Depression of DMI has been found in various studies when fat is supplemented, and this is thought to involve a negative effect on rumen fermentation or gut motility (Allen, 2000). Furthermore, Allen (2000) explains that as the concentration of calcium salts of palm FA supplementation increases, DMI decreases. Importantly, feeding fat to lactating cows can increase circulating cholecystokinin (CCK) (Choi and Palmquist, 1996), which not only stimulates digestion of fat and protein but also acts as a hunger suppressant in cows (Choi and Palmquist, 1996). Action of CCK on satiety signals either act directly from brain satiety centers, or from peripheral action of gut CCK involving gastricemptying inhibition as well as activation of neurons that inhibit satiety centers in the brain (Allen, 2000).

Supplementation of dietary fats has resulted in a hyperphagic effect in few studies (Allen, 2000; Mosley et al., 2007). However, it is known that UFA have a greater negative effect on DMI than SFA supplements (Onetti and Grummer, 2004). This may explain the decreased DMI observed in studies that utilize tallow as a fat supplement, since approximately $50 \%$ of fatty acid in tallow are unsaturated, consisting predominately of C18:1 (Onetti and Grummer, 2004). In addition to its effects on DMI, supplemental fat also influences feed efficiency in lactating dairy cows. Feed efficiency is defined as the ability of the cow to convert feed nutrients into milk and milk components and is normally measured using DMI and ECM or 3.5\% fat-corrected milk (3.5\% FCM), which corrects for the energy and fat content of milk, respectively (Maulfair et al., 
2011). Studies have confirmed that SFA, particularly C16:0, supplementation to dairy cows increases both ECM and 3.5\% FCM feed efficiency (Mosley et al., 2007; Piantoni et al., 2013).

\section{Milk yield and composition}

Typically, providing supplemental fat to lactating dairy cows increases milk and milk fat yield. A meta-analysis by Rabiee et al. (2012) found that supplementing dietary fat to lactating cows can increase milk yield by an average of $1.05 \mathrm{~kg} / \mathrm{d}$. Additionally, the response in milk fat percentage to SFA supplementation varies by type of supplement, but dietary SFA tend to increase milk fat percent (Mosley et al., 2007; Piantoni et al., 2013; Rabiee et al., 2012). Typically, fat supplements decrease milk protein percent, and have varying effects on protein yield. Limited experiments have observed decreased protein yield (Rabiee et al., 2012), while others observed an increased protein yield in milk with SFA supplementation (Wang et al., 2010). Finally, feeding SFA increases ECM and 3.5\% FCM, particularly with C16:0 feeding (Piantoni et al., 2013; Rico et al., 2014).

Degree of saturation may contribute to the variety of milk production and composition responses associated with various fat supplements (Harvatine and Allen, 2005). For instance, UFA decrease DMI compared with SFA leading to decreased milk yield and components (Harvatine and Allen, 2005). Similarly, the more unsaturated a supplement, the greater decreases in milk fat concentration and yield are observed (Harvatine and Allen, 2005).

\section{Milk fatty acid composition}

Typical fatty acid composition in dairy cow milk consists of around 5\% polyunsaturated fat (PUFA), 25\% MUFA, and 75\% SFA, and supplemental fat will change the profile of milk saturation (Grummer, 1991). Short-chain fatty acids are synthesized de novo in the mammary 
gland, while most LCFA are taken up by the mammary gland through LPL and incorporated into milk fat (Drackley, 2004). When saturated fats such as C16:0 are supplemented to lactating dairy cows, concentration and yield of C16:0 increases in circulation (in the form of TAG-rich chylomicron), increasing availability for mammary uptake and incorporation of C16:0 into milk fat (Grummer, 1991). Increased incorporation of C16:0 into milk fat can decreases the incorporation of fatty acid such as C18:0, C18:1 cis-9, and SCFA in milk (Loften et al., 2014). The decrease in SCFA during C16:0 supplementation is thought to be due to an increase in concentration of LCFA availability for the mammary gland from circulation, a response associated with the deactivation of ACC, a rate limiting enzyme required for fatty acid synthesis (Loften et al., 2014). With this in mind, many studies that feed supplemental C16:0 often see decreased de novo synthesized fatty acid and the accumulation of butyrate (a primer for fatty acid synthase) in milk during supplementation (Glasser et al., 2008). In addition to fatty acid supplementation affecting milk fatty acid profiles, mammary desaturase activity increases variability of milk fat (Grummer, 1991). In the mammary gland, desaturases convert SFA to MUFA, which is thought to ensure fluidity of milk fat for secretion from the epithelial cell (Grummer, 1991).

\section{Metabolic responses}

The effects of supplementing fatty acids to lactating dairy cows on energy metabolism have not been widely examined. Data available shows that circulating NEFA is elevated in cows supplemented with SFA during lactation (Piantoni et al., 2013; Rico et al., 2014), and the concentration of NEFA is higher during C16:0 feeding compared to C18:0 supplementation (Rico et al., 2014). Once SFA greater than C12 are ingested, they are converted to their CoA derivatives and re-esterified to TAG after being absorbed in the small intestine (Bach and 
Babayan, 1982), and subsequently packaged into chylomicron and hydrolyzed by LPL in tissues (Christie et al., 1986). Therefore, the elevated NEFA observed with SFA feeding could be in part due to dietary fatty acid intake. Additionally, few experiments have observed SFA supplements increasing the concentration of circulating glucose and insulin (Rico et al., 2014). When observed, increased circulating glucose is thought to be in part due to a decrease in SFA-induced insulin-regulated inhibition of hepatic gluconeogenesis (Funaki, 2009). Additionally, elevations in circulating insulin during dietary intake of SFA is thought to be associated with a decrease in insulin sensitivity in monogastric animals, thereby leading to elevated levels of plasma insulin (Funaki, 2009; Kennedy et al., 2008). The relationship between dietary intake of SFA and changes in insulin sensitivity requires further investigation.

In contrast to NEFA, glucose, and insulin, limited data is available on the circulating levels of TAG and cholesterol during supplemental SFA feeding in ruminants. However, existing data shows that supplementing SFA to lactating cows has no effect on circulating TAG levels (Piantoni et al., 2013). Conversely, increased concentration of cholesterol in plasma is often observed in dairy cows on a SFA supplement (Bremmer et al., 1998; Andersen et al., 2008). Palmitic acid is considered hypercholesterolemic (Fernandez and West, 2005). Fernandez and West (2005) suggest that elevated cholesterol with C16:0 feeding may be due increased formation and reduced turnover of low-density lipoproteins.

\section{Mechanisms of insulin resistance}

During lactation, glucose utilization by the mammary gland is the metabolic priority in dairy cows (Bell and Bauman, 1997). To account for enhanced glucose uptake by the mammary gland, adipose and skeletal muscle tissues decrease glucose utilization. A review by Bell and 
Bauman (1997) reveals that in order to spare glucose for lactose synthesis, adipose and skeletal muscle become resistant to the action of insulin and the liver increases the rate of gluconeogenesis. Adipose tissue insulin resistance leads to an increase in NEFA mobilization and decreased glucose use for lipogenesis (Bauman and Currie, 1980). The response of skeletal muscle to insulin resistance is an increase in AA mobilization, which is used for both hepatic gluconeogenesis and milk protein synthesis in the mammary gland (Bell and Bauman, 1997). Although induction of adipose and skeletal muscle insulin resistnance is recognized as a hallmark of the transition period, the cause of these changes remains elusive in dairy cows. However, research suggests impairment of proteins in the insulin signaling pathway downstream of phosphoinositol 3-kinase (Bell and Bauman, 1997; Zachut et al., 2013).

In addition to homeorhetic adaptations to lactation causing insulin resistance, there is evidence of an association between fatty acids and insulin resistance in dairy cows. A review by De Koster and Opsomer (2013) details the associations between NEFA and severity of insulin resistance in dairy cows. Levels of circulating NEFA are negatively correlated with insulinstimulated glucose uptake when dairy cows undergo an insulin challenge (De Koster and Opsomer, 2013). Additionally, cows overfed during the dry period had elevated NEFA mobilization compared to lean cows, and a lower glucose clearance rate during a glucose challenge (De Koster and Opsomer, 2013). Finally, Rico et al. (2015) found that the level of NEFA in overweight cows correlates to severity of estimated insulin resistance during parturition. In addition to overweight cows displaying elevated insulin resistance, research suggests that dietary SFA decreases sensitivity to insulin (Pires et al., 2007). Recently, Pires et al. (2007) induced hyperlipidemia in dairy cows through intravenously infusing a tallow emulsion consisting of $25 \% \mathrm{C} 16: 0$. The tallow emulsion caused elevated NEFA, insulin, and 
glucose, as well as decreased glucose tolerance, suggesting that fatty acids caused the cows to become less sensitive to insulin action (Pires et al., 2007). Although the mechanism of fatty acidinduced insulin resistance in dairy cows has yet to be exposed, Pires et al. (2007) suggests that availability of SFA increases long-chain acyl-CoA and DAG that may interfere with insulin signaling. Additionally, Zachut et al. (2013) discovered that during a postpartmum glucose challenge, Akt phosphorylation was sustained in liver, implying sensitivity to insulin. However, Akt phosphorylation was diminished in adipose tissue during a glucose challenge, suggesting that adipose tissue insulin resistance and elevated lipolysis in lactating dairy cows is due in part to blocking insulin signaling pathway at Akt (Zachut et al., 2013).

In monogastrics, elevated intake of SFA and elevated body fat are known to lead to accumulation of lipid mediators that antagonize insulin action and cause insulin resistance in liver, muscle, and adipose tissues (Barbour et al., 2007; DeFronzo, 2010). Specifically, it is accepted that in monogastrics, the toxic lipid mediator ceramide, which is upregulated by SFA, directly blocks phosphorylation of Akt in the insulin signaling pathway to cause insulin resistance (Larsen and Tennagels, 2014). The similarities between insulin resistance in monogastrics and ruminants suggests that ceramides may play a causal role in inducing insulin resistance in dairy cows by blocking Akt phosphorylation. Furthermore, enhanced NEFA mobilization and SFA intake may increase ceramide-induced insulin resistance in dairy cows. 


\section{Literature Cited}

Allen, M. S. 2000. Effects of diet on short-term regulation of feed intake by lactating dairy cattle. J. Dairy Sci. 83:1598-1624.

Amaral, D. M., J. J. Veenhuizen, J. K. Drackley, M. H. Cooley, A. D. Mcgilliard, and J. W. Young. 1990. Metabolism of propionate, glucose, and carbon dioxide as affected by exogenous glucose in dairy cows at energy equilibrium1. J. Dairy Sci. 73:1244-1254.

Andersen, J. B., C. Ridder, and T. Larsen. 2008. Priming the cow for mobilization in the periparturient period: Effects of supplementing the dry cow with saturated fat or linseed. J. Dairy Sci. 91:1029-1043.

Armentano, L. E. 1992. Ruminant hepatic metabolism of volatile fatty acids, lactate and pyruvate. J Nutr 122:838-842.

Aschenbach, J. R., N. B. Kristensen, S. S. Donkin, H. M. Hammon, and G. B. Penner. 2010. Gluconeogenesis in dairy cows: The secret of making sweet milk from sour dough. Life 62:869-877.

Bach, A. C. and V. K. Babayan. 1982. Medium-chain triglycerides: An update. Am. J. Clin. Nutr. 36:950-962.

Baird, G. D., J. G. V. D. Walkt, and E. N. Bergman. 1983. Whole-body metabolism of glucose and lactate in productive sheep and cows. Br. J. Nutr. 50:249-265.

Bar-Pelled, U., E. Maltz, I. Bruckental, Y. Folman, Y. Kali, H. Gacitua, A. R. Lehrer, C. H. Knight, B. Robinson, H. Voet, and H. Tagari. 1995. Relationship between frequent milking or suckling in early lactation and milk production of high producing dairy cows. J. Dairy Sci. 78:2726-2736.

Barber, M. C., R. A. Clegg, M. T. Travers, and R. G. Vernon. 1997. Lipid metabolism in the lactating mammary gland. Biochimica et Biophysica Acta (BBA) - Lipids Lipid Met. 1347:101-126.

Barbour, L., C. Mccurdy, T. Hernandez, J. Kirwin, P. Catalano, and F. J. 2007. Cellular mechanisms for insulin resistance in normal pregnancy and gestational diabetes. Diabetes Care 30:S112-S119.

Barthel, A. and D. Schmoll. 2003. Novel concepts in insulin regulation of hepatic gluconeogenesis. Am J Physiol Endocrinol Metab 285:E685-E692. 
Bauman, D. E. and W. B. Currie. 1980. Partitioning of nutrients during pregnancy and lactation: A review of mechanisms involving homeostasis and homeorhesis. J. Dairy Sci. 63:15141529.

Baumrucker, C. R. 1986. Insulin like growth factor 1 (igf-1) and insulin stimulates lactating bovine mammary tissue DNA synthesis and milk production in vitro. J. Dairy Sci. 69:120.

Bell, A. W. 1995. Regulation of organic nutrient metabolism during transition from late pregnancy to early lactation. J. Anim. Sci. 73:2804-2819.

Bell, A. W. and D. E. Bauman. 1997. Adaptations of glucose metabolism during pregnancy and lactation. J. Mammary Gland Biol. Neoplasia 2:265-278.

Bergman, E. N. 1990. Energy contributions of volatile fatty acids from the gastrointestinal tract in various species. Physiological Reviews 70:567-590.

Bionaz, M., W. Hurley, and J. Loor. 2012. Milk protein synthesis in the lactating mammary gland: Insights from transcriptomics analyses. Milk protein.

Bremmer, D. R., L. D. Ruppert, J. H. Clark, and J. K. Drackley. 1998. Effects of chain length and unsaturation of fatty acid mixtures infused into the abomasum of lactating dairy cows. J. Dairy Sci. 81:176-188.

Choi, B. and D. L. Palmquist. 1996. High fat diets increase plasma cholecystokinin and pancreatic polypeptide, and decrease plasma insulin and feed intake in lactating cows. J. Nutr. 126:2913-2919.

Christie, W. W., R. C. Noble, and R. A. Clegg. 1986. The hydrolysis of very low density lipoproteins and chylomicrons of intestinal origin by lipoprotein lipase in ruminants. Lipids 21:252-253.

Coleman, R. A. and D. P. Lee. 2004. Enzymes of triacylglycerol synthesis and their regulation. Prog. Lipid Res. 43:134-176.

De Koster, J. D. and G. Opsomer. 2013. Insulin resistance in dairy cows. Vet. Clin. N. Am-Food A. 29:299-322.

Defronzo, R. A. 2010. Insulin resistance, lipotoxicity, type 2 diabetes and atherosclerosis: The missing links. The claude bernard lecture 2009. Diabetologia 53:1270-1287.

Drackley, J. K. 2004. Overview of fat digestion and metabolism in dairy cows. University of Illinois. 
Drackley, J. K., T. R. Overton, and G. N. Douglas. 2001. Adaptations of glucose and long-chain fatty acid metabolism in liver of dairy cows during the periparturient period. J. Dairy Sci. 84, Supplement:E100-E112.

Enjalbert, F., M. Nicot, C. Bayourthe, and R. Moncoulon. 1998. Duodenal infusions of palmitic, stearic, or oleic acids differently affect mammary gland metabolism of fatty acids in lactating dairy cows. J. Nutr. 128:1525-1532.

Fernandez, M. and K. West. 2005. Mechanisms by which dietary fatty acids modulate plasma lipids. J. Nutr. 135:2075-2207.

Funaki, M. 2009. Saturated fatty acids and insulin resistance. J. Med. Invest. 56:88-92.

Glasser, F., A. Ferlay, M. Doreau, P. Schmidely, D. Sauvant, and Y. Chilliard. 2008. Long-chain fatty acid metabolism in dairy cows: A meta-analysis of milk fatty acid yield in relation to duodenal flows and de novo synthesis. J. Dairy Sci. 91:2771-2785.

Grummer, R. R. 1991. Effect of feed on the composition of milk fat. J. Dairy Sci. 74:3244-3257.

Harvatine, K. J. and M. S. Allen. 2005. The effect of production level on feed intake, milk yield, and endocrine responses to two fatty acid supplements in lactating cows. J. Dairy Sci. 88:4018-4027.

Herdt, T. H. 2000. Ruminant adaptation to negative energy balance: Influences on the etiology of ketosis and fatty liver. Vet. Clin. N. Am-Food A. 16:215-230.

Hopkins, B. A. and L. W. Whitlow. 2015. Effective use of protein in early lactation diets. Pages 1-4. North Carolina State University.

Howlett, A. R. and M.J. Bissell. 1990. Regulation of mammary epithelial cell function: A role for stromal and basement membrane matrices. Protoplasma 159:85-95.

Husveth, F. 2011. Physiological and reproductional aspects of animal production. Debreceni Egyetem, Nyugat-Magyarországi Egyetem, Pannon Egyetem.

Jenkins, T. C. 1993. Lipid metabolism in the rumen. J. Dairy Sci. 76:3851-3863.

Jensen, R. G. 2002. The composition of bovine milk lipids: January 1995 to december 2000. J. Dairy Sci. 85:295-350.

Kennedy, A., K. Martinez , C. Chuang, K. Lapoint, and M. Mcintosh. 2008. Saturated fatty acidmediated inflammation and insulin resistance in adipose tissue: Mechanisms of action and implications. J. Nutr. 139:1-4. 
Laliotis, G. P., I. Bizelis, and E. Rogdakis. 2010. Comparative approach of the de novo fatty acid synthesis (lipogenesis) between ruminant and non ruminant mammalian species: From biochemical level to the main regulatory lipogenic genes. Curr. Genomics 11:168-183.

Larsen, P. J. and N. Tennagels. 2014. On ceramides, other sphingolipids and impaired glucose homeostasis. Mol. Metab. 3:252-260.

Linn, J. G. 1988. Factors affecting the composition of milk from dairy cows.

Loften, J. R., J. G. Linn, J. K. Drackley, T. C. Jenkins, C. G. Soderholm, and A. F. Kertz. 2014. Invited review: Palmitic and stearic acid metabolism in lactating dairy cows. J. Dairy Sci. 97:4661-4674.

Lohrenz, A. K., K. Duske, U. Schönhusen, B. Losand, H. M. Seyfert, C. C. Metges, and H. M. Hammon. 2011. Glucose transporters and enzymes related to glucose synthesis in small intestinal mucosa of mid-lactation dairy cows fed 2 levels of starch. J. Dairy Sci. 94:4546-4555.

Lollivier, V. and P. Marnet. 2005. Galactopoietic effect of milking in lactating holstein cows: Role of physiological doses of oxytocin. Livestock Production Science 95:131-142.

Månsson, H. L. 2008. Fatty acids in bovine milk fat. Food Nutr. Res. 52:1-3.

Maulfair, D., J. Heinrichs, and V. Ishler. 2011. Feed efficiency for lactating dairy cows and its relationship to income over feed costs. DAS., Pennsylvania State University Extension.

Mcnamara, J. P. and J. K. Hillers. 1986. Adaptations in lipid metabolism of bovine adipose tissue in lactogenesis and lactation J. Lipid Res. 27:150-157.

Mellenberger, R. W., D. E. Bauman, and D. R. Nelson. 1973. Metabolic adaptions during lactogenesis: Fatty acid and lactose synthesis in cow mammary tissue. Biochem. J. 136:741-748.

Mosley, S. A., E. E. Mosley, B. Hatch, J. I. Szasz, A. Corato, N. Zacharias, D. Howes, and M. A. Mcguire. 2007. Effect of varying levels of fatty acids from palm oil on feed intake and milk production in holstein cows. J. Dairy Sci. 90:987-993.

Nafikov, R. A. and D. C. Beitz. 2007. Carbohydrate and lipid metabolism in farm animals. J. Nutr. 137:702-705.

Neville, M. C. and J. Morton. 2001. Physiological and endocrine changes underlying human lactogenesis ii. J Nutr 135:3005S-3008S.

Neville, M. C., T.B. McFadden, I. Forsyth. 2002. Hormonal regulation of mammry differentiation and milk secretion. J. Mammary Gland Biol. Neoplasia 7:49-66. 
NRC. 1988. Designing foods: Animal product options in the marketplace. A. N. R. Council, ed. Natl. Acad. Sci., Washington, DC.

NRC. 2001. Nutritional requirements of dairy cattle. 7th rev. ed. Natl. Acad. Sci., Washington, DC.

Onetti, S. G. and R. R. Grummer. 2004. Response of lactating cows to three supplemental fat sources as affected by forage in the diet and stage of lactation: A meta-analysis of literature. Anim. Feed Sci. Technol. 115:65-82.

Choi, B. and D.L. Palmquist. 1996. High fat diets increase plasma cholecystokinin and pancreatic polypeptide, and decrease plasma insulin and feed intake in lactating cows. J. Nutr. 126:2913-2919.

Palmquist, D. L. 2006. Milk fat: Origin of fatty acids and influence of nutritional factors thereon. Pages 43-92 in Advanced dairy chemistry volume 2 lipids. P. F. Fox and P. L. H. McSweeney, ed. Springer US.

Piantoni, P., A. L. Lock, and M. S. Allen. 2013. Palmitic acid increased yields of milk and milk fat and nutrient digestibility across production level of lactating cows. J. Dairy Sci. 96:7143-7154.

Pires, J. A., A. H. Souza, and R. R. Grummer. 2007. Induction of hyperlipidemia by intravenous infusion of tallow emulsion causes insulin resistance in holstein cows. J. Dairy Sci. 90:2735-2744.

Rabiee, A. R., K. Breinhild, W. Scott, H. M. Golder, E. Block, and I. J. Lean. 2012. Effect of fat additions to diets of dairy cattle on milk production and components: A meta-analysis and meta-regression. J. Dairy Sci. 95:3225-3247.

Rasmussen, B.B. and R.R. Wolfe. 1999. Regulation of fatty acid oxidation in skeletal muscle. Annu. Rev. Nutr. 19:465-484.

Reynolds, C. K., D. L. Harmon, and M. J. Cecava. 1994. Absorption and delivery of nutrients for milk protein synthesis by portal-drained viscera1. J. Dairy Sci. 77:2787-2808.

Rico, J. E., M. S. Allen, and A. L. Lock. 2014. Compared with stearic acid, palmitic acid increased the yield of milk fat and improved feed efficiency across production level of cows. J. Dairy Sci. 97:1057-1066.

Rico, J. E., V. V. R. Bandaru, J. M. Dorskind, N. J. Haughey, and J. W. McFadden. 2015. Plasma ceramides are elevated in overweight holstein dairy cows experiencing greater lipolysis and insulin resistance during the transition from late pregnancy to early lactation. J. Dairy Sci. 98:7757-7770. 
Rius, A. G., J. a. D. R. N. Appuhamy, J. Cyriac, D. Kirovski, E. Becvar, J. Escobar, M. L. Mcgilliard, B. J. Bequette, R. M. Akers, and M. Hanigan. 2010. Regulation of protein synthesis in mammary glands of lactating dairy cows by starch and amino acids. J. Dairy Sci. 93:3114-3127.

Tirone, T. A. and F. C. Brunicardi. 2001. Overview of glucose regulation. World J. Surg. 25:461-467.

Van Houtert, M. F. J. 1993. The production and metabolism of volatile fatty acids by ruminants fed roughages: A review. Anim. Feed Sci. Technol. 43:189-225.

Wang, J. P., D. P. Bu, J. Q. Wang, X. K. Huo, T. J. Guo, H. Y. Wei, L. Y. Zhou, R. R. Rastani, L. H. Baumgard, and F. D. Li. 2010. Effect of saturated fatty acid supplementation on production and metabolism indices in heat-stressed mid-lactation dairy cows. J. Dairy Sci. 93:4121-4127.

Wiltrout, D. W. and L. D. Satter. 1971. Contribution of propionate to glucose synthesis in the lactating and nonlactating cow. J. Dairy Sci. 55:307-317.

Zachut, M., H. Honig, S. Striem, Y. Zick, S. Boura-Halfon, and U. Moallem. 2013. Periparturient dairy cows do not exhibit hepatic insulin resistance, yet adipose-specific insulin resistance occurs in cows prone to high weight loss. J. Dairy Sci. 96:5656-5669.

Zeng, G., F. H. Nystrom, L. V. Ravichandran, L. Cong, M. Kirby, H. Mostowski, and M. J. Quon. 2000. Roles for insulin receptor, pi3-kinase, and akt in insulin-signaling pathways related to production of nitric oxide in human vascular endothelial cells. Circulation 101:1539-1545.

Zhao, F.-Q., W. T. Dixon, and J. J. Kennelly. 1996. Localization and gene expression of glucose transporters in bovine mammary gland. Comp. Biochem. Physiol. B. 115:127-134.

Zheng, Y., J. S. Scow, J. A. Duenes, and M. G. Sarr. 2012. Mechanisms of glucose uptake in intestinal cell lines: Role of glut2. Surgery 151:13-25. 


\section{Chapter 3}

\section{INCREASING PALMITIC ACID INTAKE ENHANCES MILK PRODUCTION AND PREVENTS GLUCOSE-STIMULATED NEFA DISAPPEARANCE WITHOUT MODIFYING SYSTEMIC GLUCOSE TOLERANCE IN MID-LACTATION DAIRY COWS}

\section{Introduction}

Dairy cows experience an elevated demand for circulating glucose at the onset of lactation due to an increased requirement by the mammary gland for lactose synthesis (Bell, 1995). As a means to partition glucose towards the mammary gland, early lactation cows will develop insulin resistance to decrease glucose uptake by skeletal muscle and adipose tissues (Bell and Bauman, 1997; De Koster and Opsomer, 2013). Concomitantly, adipose tissue lipolysis will provide NEFA for $\beta$-oxidation in peripheral tissues and re-esterification in the mammary gland (McNamara and Hillers, 1986; Zachut et al., 2013). Because insulin is an anti-lipolytic hormone, insulin resistance can further facilitate the mobilization of NEFA from adipose tissue. These homeorhetic adaptations are characteristic metabolic shifts in energy metabolism unique to early lactation cows coping with energy insufficiency and experiencing rapid increases in milk production. As lactation progresses beyond peak daily milk yield, insulin-stimulated glucose uptake by peripheral tissues increases and circulating NEFA availability declines to minimal levels (McNamara and Hillers, 1986; Bell and Bauman, 1997). Furthermore, the restoration of positive energy balance is accompanied by the beginning of milk production decline.

The supplementation of SFA is a nutritional management practice utilized by producers to increase the energy density of diets offered to cows during lactation. Feeding cows palmitic acid (C16:0) has been reported to improve feed efficiency (Rico et al., 2014a), and increase milk yield and milk fat yield without reducing DMI (Piantoni et al., 2013), as compared with a no 
supplemental fat control. Feeding C16:0 at 1 to $4 \%$ of ration DM has resulted in gains of milk and milk fat yield ranging from $0.8-3.3 \mathrm{~kg} / \mathrm{d}$ and $0.08-0.40 \mathrm{~kg} / \mathrm{d}$, respectively (Mosley et al., 2007; Wang et al., 2010; Piantoni et al., 2013; Rico et al., 2014b). Some inconsistencies in milk production and DMI responses to C16:0 have been observed, but are likely due to differences in study design including C16:0 feeding level, stage of lactation, and length of treatment. Supplementing C16:0 clearly increases the energy density of diets fed to cows; however, favorable lactation outcomes may not completely depend on the energy content of the supplemental C16:0. For instance, C16:0 feeding increases ECM and 3.5\% FCM when compared with C18:0 supplementation (Rico et al., 2014b).

Supplementing mid-lactation cows with C16:0 can influence metabolic health status, albeit moderately (Pires et al., 2007; Piantoni et al., 2013; Rico et al., 2014b). An increase in circulating NEFA with C16:0 supplementation is a consistent observation, relative to C18:0 (Rico et al., 2014b) or without supplemental fat (Piantoni et al., 2013). Also, an elevation in plasma insulin coincides with an increase in C16:0 availability both at the basal level and during a glucose challenge (Pires et al., 2007; Piantoni et al., 2013). To our knowledge, the effects of high purity C16:0 feeding on insulin sensitivity measurements in mid-lactation cows are limited to a single study (Piantoni et al., 2013). Although Piantoni et al. (2013) did not document any changes in glucose or insulin tolerance in mid-lactation cows supplemented with $\mathrm{C} 16: 0$ at $2 \%$ of diet DM for $21 \mathrm{~d}$, the effects of C16:0 provided at a greater dietary level for an extended duration on estimated insulin sensitivity, glucose tolerance, and glucose-stimulated NEFA disappearance have not been characterized. In monogastric animals, SFA antagonize insulin action in adipose and skeletal muscle tissues by inhibiting insulin-stimulated protein kinase B activation (Summers, 2006; Zachut et al., 2013), a response that is accompanied by the accrual of ceramide 
(Summers, 2006). Interestingly, insulin resistant early lactation cows experience an elevation in circulating C16:0 and ceramide (Contreras et al., 2010; Rico et al., 2015). Because the availability of lipolysis-derived C16:0 declines with the progression of lactation, an increase in C16:0 availability in circulation and tissues may be a means of restoring homeorhetic nutrient partitioning to increase milk production. The magnitude of glucose intolerance may depend on C16:0 availability; therefore, our objective was to continuously characterize the effects of extended C16:0 supplementation on milk production outcomes, metabolic status, and response to a glucose challenge in mid-lactation dairy cows. We hypothesized that supplementing C16:0 at a high dietary level for a prolonged duration would increase milk and milk fat yield, and decrease insulin sensitivity.

\section{Materials and methods}

\section{Experimental design}

Dairy cows experience an elevated demand for circulating glucose at the onset of lactation due to an increased requirement by the mammary gland for lactose synthesis (Bell, 1995). As a means to partition glucose towards the mammary gland, early lactation cows will develop insulin resistance to decrease glucose uptake by skeletal muscle and adipose tissues (Bell and Bauman, 1997; De Koster and Opsomer, 2013). Concomitantly, adipose tissue lipolysis will provide NEFA for $\beta$-oxidation in peripheral tissues and re-esterification in the mammary gland (McNamara and Hillers, 1986; Zachut et al., 2013). Because insulin is an anti-lipolytic hormone, insulin resistance can further facilitate the mobilization of NEFA from adipose tissue. These homeorhetic adaptations are characteristic metabolic shifts in energy metabolism unique to early lactation cows coping with energy insufficiency and experiencing rapid increases in milk 
production. As lactation progresses beyond peak daily milk yield, insulin-stimulated glucose uptake by peripheral tissues increases and circulating NEFA availability declines to minimal levels (McNamara and Hillers, 1986; Bell and Bauman, 1997). Furthermore, the restoration of positive energy balance is accompanied by the beginning of milk production decline.

The supplementation of SFA is a nutritional management practice utilized by producers to increase the energy density of diets offered to cows during lactation. Feeding cows palmitic acid (C16:0) has been reported to improve feed efficiency (Rico et al., 2014a), and increase milk yield and milk fat yield without reducing DMI (Piantoni et al., 2013), as compared with a no supplemental fat control. Feeding C16:0 at 1 to $4 \%$ of ration DM has resulted in gains of milk and milk fat yield ranging from $0.8-3.3 \mathrm{~kg} / \mathrm{d}$ and $0.08-0.40 \mathrm{~kg} / \mathrm{d}$, respectively (Mosley et al., 2007; Wang et al., 2010; Piantoni et al., 2013; Rico et al., 2014b). Some inconsistencies in milk production and DMI responses to C16:0 have been observed, but are likely due to differences in study design including C16:0 feeding level, stage of lactation, and length of treatment. Supplementing C16:0 clearly increases the energy density of diets fed to cows; however, favorable lactation outcomes may not completely depend on the energy content of the supplemental C16:0. For instance, C16:0 feeding increases ECM and 3.5\% FCM when compared with C18:0 supplementation (Rico et al., 2014b).

Supplementing mid-lactation cows with C16:0 can influence metabolic health status, albeit moderately (Pires et al., 2007; Piantoni et al., 2013; Rico et al., 2014b). An increase in circulating NEFA with C16:0 supplementation is a consistent observation, relative to C18:0 (Rico et al., 2014b) or without supplemental fat (Piantoni et al., 2013). Also, an elevation in plasma insulin coincides with an increase in C16:0 availability both at the basal level and during a glucose challenge (Pires et al., 2007; Piantoni et al., 2013). To our knowledge, the effects of 
high purity C16:0 feeding on insulin sensitivity measurements in mid-lactation cows are limited to a single study (Piantoni et al., 2013). Although Piantoni et al. (2013) did not document any changes in glucose or insulin tolerance in mid-lactation cows supplemented with $\mathrm{C} 16: 0$ at $2 \%$ of diet DM for $21 \mathrm{~d}$, the effects of C16:0 provided at a greater dietary level for an extended duration on estimated insulin sensitivity, glucose tolerance, and glucose-stimulated NEFA disappearance have not been characterized. In monogastric animals, SFA antagonize insulin action in adipose and skeletal muscle tissues by inhibiting insulin-stimulated protein kinase B activation (Summers, 2006; Zachut et al., 2013), a response that is accompanied by the accrual of ceramide (Summers, 2006). Interestingly, insulin resistant early lactation cows experience an elevation in circulating C16:0 and ceramide (Contreras et al., 2010; Rico et al., 2015). Because the availability of lipolysis-derived C16:0 declines with the progression of lactation, an increase in C16:0 availability in circulation and tissues may be a means of restoring homeorhetic nutrient partitioning to increase milk production. The magnitude of glucose intolerance may depend on C16:0 availability; therefore, our objective was to continuously characterize the effects of extended C16:0 supplementation on milk production outcomes, metabolic status, and response to a glucose challenge in mid-lactation dairy cows. We hypothesized that supplementing $\mathrm{C} 16: 0$ at a high dietary level for a prolonged duration would increase milk and milk fat yield, and decrease insulin sensitivity.

\section{Glucose tolerance tests}

Glucose tolerance tests (GTT) were performed on $\mathrm{d}-1,24$, and 49 relative to the start of treatment using previously described methods (Pires et al., 2007; Schoenberg et al., 2012). Briefly, a jugular catheter was inserted $24 \mathrm{~h}$ prior to the GTT, and patency was maintained by flushing with heparinized saline every $12 \mathrm{~h}$. Coinciding with the removal of feed at $0800 \mathrm{~h}$, cows 
were intravenously infused with $300 \mathrm{mg}$ of glucose (dextrose, $50 \% \mathrm{wt} / \mathrm{vol}$ ) per $\mathrm{kg}$ of BW.

Glucose infusion occurred within $8 \pm 0.88 \mathrm{~min}$, and was followed by a $10-\mathrm{mL}$ saline flush. Blood samples $(10 \mathrm{~mL})$ were collected at $-10,0,10,20,30,40,60,90,120,150$, and 180 min relative to initiation of glucose infusion. Blood was processed as described above. Feed was provided immediately following the completion of the GTT.

\section{Sample analyses}

Individually composited feed ingredients were analyzed for NDF with heat-stable $\alpha$ amylase and sodium sulfite (Van Soest et al., 1991), CP (AOAC International, 2000; method 990.03), and starch (Hall, 2009) by Cumberland Valley Analytical Services Inc. (Cumberland, MD).

Plasma samples were analyzed in duplicate for glucose, NEFA, insulin, TAG, and total cholesterol. Plasma concentrations of glucose, NEFA, TAG, and cholesterol were determined by enzymatic methods using commercial kits (Autokit Glucose, HR series NEFA-HR, L-Type TAG M, and Cholesterol E respectively; Wako Chemicals USA Inc., Richmond, VA). Plasma insulin concentrations were determined by ELISA (Mercodia Bovine Insulin ELISA; Mercodia AB, Uppsala, Sweden). Spectrophotometric measurements were conducted using a SpectraMax Plus 384 Microplate Reader (Molecular Devices, Sunnyvale, CA). Intra- and interassay CV were 4.6 and $2.6 \%, 3.7$ and $3.7 \%, 2.1$ and $2.8 \%, 3.1$ and $6.1 \%$, and 3.0 and $7.0 \%$ for glucose, NEFA, TAG, total cholesterol, and insulin, respectively.

Individual milk samples were analyzed for fat, true protein, and lactose concentrations, as well as MUN using mid-infrared spectroscopy, and SCC was determined by flow cytometry (Dairy One, Hagerstown, MD; AOAC, 1990; method 972.160) within 1 wk of collection. For analysis of milk FA composition, four individual milk samples were composited based on milk 
fat yield to represent the covariate period (d -5 and -4), week 3 (d 20 and 21), and week 7 (d 45 and 46) of the treatment period, and the completion of the post-treatment period (d 62 and 63 , relative to the start of treatment). Samples were centrifuged at $17,800 \times g$ for $30 \mathrm{~min}$ at $4^{\circ} \mathrm{C}$ and fat cakes were collected. Lipids from the fat cakes were extracted, methylated, and FA composition determined by GLC, according to previously described methods (Lock et al., 2013). Short chain FA methyl esters were corrected for mass discrepancy using the response factors described by (Ulberth and Schrammel, 1995). Individual FA yields (g/d) were calculated using milk fat yield and FA concentration to determine yield on a mass basis, using the molecular weight of each FA while correcting for glycerol and other milk lipid classes (Piantoni et al., 2013).

\section{Calculations and statistical analysis}

Yields of ECM, 3.5\% FCM, and milk components were calculated using milk yield and components for each milking, summed for daily total, and averaged for each week of collection. Energy intake, energy balance, and feed efficiency were calculated as follows: $\mathrm{NE}_{\mathrm{L}}$ intake $=\mathrm{kg}$ of DMI $\times$ Mcal per kg of apparent dietary $\mathrm{NE}_{\mathrm{L}}$; energy balance $=\mathrm{NE}_{\mathrm{L}}$ intake $-\left(\mathrm{NE}_{\mathrm{M}}+\mathrm{NE}_{\mathrm{L}}\right)$, and feed efficiency $=\mathrm{kg}$ of ECM / kg of DMI. Plasma glucose, NEFA, and insulin concentrations were measured, and systemic insulin sensitivity estimated using the revised quantitative insulin sensitivity check index (RQUICKI) (Holtenius and Holtenius, 2007), where RQUICKI = 1/[log $($ glucose $)+\log ($ insulin $)+\log (\mathrm{NEFA})]$, and glucose $=$ basal glucose $(\mathrm{mg} / \mathrm{dL})$, insulin $=$ basal insulin $(\mu \mathrm{U} / \mathrm{mL})$, and NEFA = basal NEFA $(\mathrm{mmol} / \mathrm{L})$, such that lowered RQUICKI values indicate a reduction in insulin sensitivity, and higher values indicate elevations in insulin sensitivity. The area under the curve (AUC) for glucose and NEFA during GTT was calculated using the trapezoidal method as previously described by Pires et al. (2007). 
All data were analyzed using the MIXED model procedure of SAS (version 9.3; SAS Institute Inc., Cary, NC) according to the following model:

$\mathrm{Y}_{\mathrm{ijk}}=\mu+\mathrm{C}_{\mathrm{i}}+\mathrm{P}_{\mathrm{j}}+\mathrm{T}_{\mathrm{k}(\mathrm{i})}+\left(\mathrm{P}_{\mathrm{j}} \times \mathrm{T}_{\mathrm{k}}\right)+\mathrm{pMY}+\left(\mathrm{pMy} \times \mathrm{T}_{\mathrm{k}}\right)+\mathrm{e}_{\mathrm{ijk}}$

Where $\mathrm{Y}_{\mathrm{ijk}}=$ dependent variable, $\mu=$ overall mean, $\mathrm{C}_{\mathrm{i}}=$ random effect of cow nested within treatment ( $\mathrm{i}=1$ to 20$), \mathrm{P}_{\mathrm{j}}=$ fixed effect of sampling week $(\mathrm{j}=1$ to 4$), \mathrm{T}_{\mathrm{k}}=$ fixed effect of treatment $(\mathrm{k}=1$ to 2$), \mathrm{P}_{\mathrm{j}} \times \mathrm{T}_{\mathrm{k}}=$ interaction between sampling week and treatment, $\mathrm{pMy}=$ preliminary milk yield used as a covariate, $\mathrm{pMy} \times \mathrm{T}_{\mathrm{k}}=$ interaction between treatment and preliminary milk yield, and $\mathrm{e}_{\mathrm{ijk}}=$ residual error. Interactions were evaluated but removed from the statistical model when not significant $(P>0.10)$. For data that were evaluated continuously, effect of sampling week was replaced with the effect of sampling day. Normality of the residuals was checked with normal probability and box plots and homogeneity of variances with plots of residual versus predicted values. When necessary, data were transformed. Preplanned contrasts were used to evaluate the differences between cows at each time point. Significance was declared at $P<0.05$ and trends at $P<0.10$. Studentized residual values $>3.0$ or $<-3.0$ were considered outliers and removed from the analysis (typically 1 per response variable). All results are expressed as least squares means and their standard errors, unless stated otherwise.

\section{Results}

The C16:0-enriched fat supplement was included at 3.9\% of ration DM, with soyhulls substituted in the control treatment (Table 1). Content of DM, NDF, CP, and starch, were comparable between treatments. Ether extract and $\mathrm{NE}_{\mathrm{L}}$ were higher in PALM, relative to control. 
All cows had similar milk yield, ECM, 3.5\% FCM, DMI, energy intake, BW, and BCS during the covariate period (Table 2).

\section{Production responses}

When analyzed continuously, PALM increased DMI by wk 6 (Figure $1 ; P<0.05$ ). Additionally, PALM increased milk yield by d 15 (26.6 vs. 32.0 kg/d, $P<0.05$; Figure 1), a response that was observed repeatedly during the remainder of treatment (e.g., $28.3 \mathrm{vs.} 32.1 \mathrm{~kg} / \mathrm{d}$ and 24.4 vs. $29.0 \mathrm{~kg} / \mathrm{d}$ for d 21 and 49 , respectively; $P \leq 0.10$ ). Post-treatment, milk yield converged for control and PALM, although intermittently (e.g., d 10 after treatment removal; 25.7 vs $29.1 \mathrm{~kg} / \mathrm{d}, P=0.06)$. Coinciding with the start of treatment, energy intake was greater in PALM-fed cows $(P \leq 0.10$; Figure 1$)$, and was elevated less frequently post-treatment.

Milk production and composition were further evaluated by pooling samples and data at wk 3 and 7 (Table 3). Similar to the continuous evaluation of milk yield, PALM-fed cows produced 14 and 19\% more milk during wk 3 and 7 , respectively $(P \leq 0.08)$; however, this response was not observed post-treatment. PALM treatment increased milk fat yield by 27 and $18 \%(P<0.01)$, ECM by 14 and $16 \%(P<0.05)$, and $3.5 \%$ FCM by 19 and $18 \%(P<0.05)$ at wk 3 and 7, respectively, and these responses remained by wk 2 post-treatment. Supplementing PALM increased milk protein yield by $15 \%$ in cows fed PALM for a 7 wk duration $(P=0.05)$, an effect that remained during the post-treatment evaluation. The PALM treatment did not modify milk fat concentration, MUN, or SCC. Although we detected a tendency for increased DMI at wk $7(P=0.06)$, we did observe an increase in energy intake (16\% average) in cows supplemented with PALM $(P<0.05)$, results that are comparable to the continuous evaluation of DMI and energy intake. Furthermore, feed efficiency tended to be greater for PALM-fed cows 
after treatment $(P=0.08)$. We did not observe any differences in BCS, BW, or energy balance for PALM versus control treatments.

\section{Milk fatty acid yields and concentrations}

Relative to control, PALM increased milk C16:0 yield by 52 and $46 \%$ by wk 3 and 7 , respectively $(P<0.001$; Table 4$)$. Similar observations were observed for milk C16:1. In contrast, the yield of C16:0 in milk was similar for both groups two weeks following the termination of treatments. Although the total yield of preformed FA in milk remained unchanged during the treatment period, milk SFA yield increased by 29 and $24 \%$ in PALM-fed cows at wk 3 and 7 , respectively $(P<0.001)$. Total yields of FA synthesized de novo, as well as MUFA and PUFA in milk remained unchanged during the treatment period. Interestingly, we observed 24 and $22 \%$ increases in yields of de novo and preformed FA in PALM cows post-treatment $(P<$ 0.01). For example, post-treatment increases in milk yields of C6:0, C8:0, C10:0, C12:0, C14:0, 18:0, cis-9 C18:1, and cis-9, cis-12 C18:2 ranged from 18 to $36 \%(P \leq 0.05)$ in PALM versus control cows.

In a similar manner, PALM modified the concentrations of milk FA (Table 5). Relative to control, PALM increased milk C16:0 concentration by 26 and $21 \%$ at wk 3 and 7, respectively $(P<0.001)$. Likewise, SFA concentration increased by 4.3 and $3.9 \%$ in PALM cows at wk 3 and 7 , respectively $(P<0.05)$. In contrast, the concentrations of unsaturated FA were lower in PALM cows. The concentrations of most de novo synthesized FA were 18 and $12 \%$ lower in PALM cows by wk 3 and 7, respectively $(P<0.01)$. For example, PALM lowered the concentrations of C6:0, C8:0, C10:0, C12:0, and C14:0 FA in milk, which ranged from 10 to $26 \%$ at wk 3 ( $P<$ 0.01). In contrast to changes in milk FA yields, we did not detect any treatment differences in the concentrations of milk FA, including C16:0, during the post-treatment period. 


\section{Plasma metabolite responses}

The PALM treatment increased circulating NEFA by 48, 93, and $60 \%$ on d 4, 6, and 8 of treatment, respectively (interaction $P<0.05$; Figure 2); however, coinciding with enhanced milk production, PALM did not affect plasma NEFA following d 8. Consistent with the advancement of lactation, the level of NEFA in plasma declined with time in all cows $(P<0.01)$. Unexpectedly, we observed a higher concentration of insulin in control-fed cows at the onset of treatment (interaction $P<0.05$; Figure 2). We also measured a gradual rise in circulating insulin with the progression of lactation $(P<0.05)$. We did not detect any changes in circulating glucose with treatment (Figure 2). In parallel with our observed plasma NEFA response, PALM cows displayed lower RQUICKI values at d 6 and 8 (38 and 35\%, respectively; $\mathrm{P}<0.01$; Figure 2), reflecting an acute decrease in estimated insulin sensitivity in PALM-fed cows. Although PALM increased circulating NEFA during the short-term, PALM did not modify circulating TAG (Figure 3). Conversely, total cholesterol concentration in plasma was 50 and $51 \%$ greater in PALM cows by wk 3 and 7 , respectively $(P<0.01$; Figure 3$)$.

Supplementing cows with PALM did not modify circulating glucose following intravenous glucose infusion during the duration of treatment (Figure 4). Furthermore, PALM did not modify glucose AUC during the GTT (Table 7). The magnitude of plasma NEFA disappearance following a glucose challenge progressively decreased with duration of PALM treatment (Figure 4). Such that PALM-fed cows had a tendency for reduced NEFA disappearance 60 min after glucose infusion (nadir of curve) on wk 3 of treatment $(P<0.10)$, a response that was significantly greater by wk 7 (interaction $P<0.001$ ). Additionally, PALM increased AUC for NEFA during the GTT (Table 7). 


\section{Discussion}

Previous research studies that evaluated the effects of C16:0-enriched supplements on milk production have included short-term study lengths, varying dietary levels of C16:0, and brief sampling windows near the end of treatment (Loften et al., 2014), collective work that have had variable production responses. Furthermore, the effects of prolonged C16:0 supplementation for $7 \mathrm{wk}$ or the effects following treatment removal on milk production and composition have not been investigated. Moreover, the relationship between C16:0 supplementation, insulin sensitivity, and nutrient partitioning in mid-lactation cows has been considered in a single study (Piantoni et al., 2013). Considering that circulating lipid availability is linked with the development of insulin resistance and nutrient partitioning during early lactation, and that increasing circulating SFA can antagonize insulin action, we chose to further explore the effects of dietary C16:0 on systemic glucose tolerance and lipolytic response following a series of glucose challenges. Because beneficial changes in milk production outcomes are inconsistent and Piantoni et al. (2013) did not observe a change in glucose tolerance when C16:0 was fed at 2\% of diet DM for 3 wk, we chose to utilize a high dietary feeding level of C16:0 (3.9\% of diet DM) relative to industry applications for a longer period of time ( $7 \mathrm{wk})$. Our feeding level was comparable to previous work by Steele (1969) and Mosley et al. (2007). We also evaluated changes in milk production and composition following the $2 \mathrm{wk}$ removal of supplemental C16:0.

Although we did not record improvements in milk yield with C16:0 until d 13 of PALM treatment, daily milk yields averaged 26.3 and $29.7 \mathrm{~kg}$ (control vs. PALM, respectively) over the duration of the 49-d treatment. Furthermore, maximum gains of $4.8 \mathrm{~kg} / \mathrm{d}$ were observed in cows consuming supplemental C16:0 at 3.9\% of diet DM (1,013 g/d) by wk 7 . Our observed increases

in milk yield are comparable to Mosley et al. (2007), who observed $3.3 \mathrm{~kg} / \mathrm{d}$ of milk produced by 
cows consuming 1,000 g/d of an C16:0-enriched supplement ( $808 \mathrm{~g} / \mathrm{d})$ for $16 \mathrm{~d}$, when compared with a non-supplemented control diet. Likewise, Steele (1969) reported increases in milk yields by $1 \mathrm{~kg} / \mathrm{d}$ in cows supplemented with $\mathrm{C} 16: 0(\sim 85 \% \mathrm{C} 16: 0)$ at $4.25 \%$ of diet for $35 \mathrm{~d}$, relative to no added fat. Comparable to Piantoni et al. (2013), we did not detect a significant change in DMI at wk 3; however, our continued gains in milk yield beyond wk 3 were coupled with a trend for increased DMI. Because treatment increased ECM at wk 3 and wk 7, and tended to increase DMI by wk 7, feed efficiency (kg of ECM / $\mathrm{kg}$ of DMI) tended to be higher in PALM-fed cows. In contrast to other studies that compared diets supplemented with C16:0 with non-supplemented controls (Steele, 1969; Mosley et al., 2007; Piantoni et al., 2013), PALM did not increase milk fat, protein, or lactose concentrations. However, PALM supplementation did increase milk fat yield ( +300 and $+200 \mathrm{~g} / \mathrm{d}$ by wk 3 and 7, respectively). At comparable C16:0 treatment levels, Mosley et al. (2007) and Steele (1969) reported gains in milk fat yields of 302 and $115 \mathrm{~g} / \mathrm{d}$, respectively. Our results also demonstrate that improvements in milk fat yield with PALM treatment are sustained for the duration of a $7 \mathrm{wk}$ treatment period. Comparable to others (Steele, 1969; Mosley et al., 2007; Piantoni et al., 2013), we did not observe changes in milk protein yield by wk 3; however, milk protein yield was greater in PALM fed cows by wk 7 (+130 g/d). Because we observed an increase in energy intake due to increased dietary C16:0, AA utilization may have been partitioned away from non-mammary tissues and towards milk protein synthesis. Similar to others (Piantoni et al., 2013; Rico et al., 2014b), we observed an increase in ECM and 3.5\% FCM by wk 3 (14 and 19\%, respectively). Because BCS and BW were not significantly different between treatments, we consider that increased energy intake may have been diverted towards milk and milk component production and away from adipose or skeletal muscle tissue accretion. Two weeks following the removal of PALM, milk yield started to converge between 
the treatment groups; however, ECM and 3.5\% FCM remained elevated in parallel with a sustained elevation in milk fat and protein yields. The post-treatment increase in ECM and 3.5\% FCM occurred in parallel with a continued increase in energy intake observed in cows previously fed PALM.

Our observed changes in milk FA yields during PALM are consistent with related studies (Mosley et al., 2007; Lock et al., 2013; Piantoni et al., 2013). Treatment with C16:0 did not affect de novo synthesized or preformed FA yields in milk during treatment; however, PALM did increase SFA yields due to an increase in C16:0 incorporation. The absence of an increase in de novo FA synthesis with enhanced milk yield may be due to the allosteric inhibition of acetylCoA carboxylase (Storry et al., 1973; Wright et al., 2002). As opposed to treatment, the removal of supplemental C16:0 for 2 wk increased de novo milk fat synthesis. Additionally, the removal of supplemental C16:0 enhanced the incorporation of preformed FA into milk fat. The observed increase in de novo and preformed FA in milk post-treatment may reflect the sustained elevation in energy intake, albeit elevated dietary energy was independent of C16:0. The cow's ability to remodel milk FA composition to maintain elevated ECM and milk fat yield for two weeks beyond C16:0 removal is intriguing, and the extent of this preservation should be further investigated.

Saturated FA feeding has been reported to increase circulating NEFA in dairy cows (Piantoni et al., 2013; Rico et al., 2014b). In our study, the basal concentrations of NEFA in plasma were elevated in PALM-fed cows exclusively during the initial two weeks of treatment, immediately prior to enhanced daily yields of milk and milk fat. The ability of supplemental SFA to increase NEFA is well documented (Grummer, 1991). For instance, Rico et al. (2014b) observed elevated plasma NEFA in mid-lactation cows fed C16:0, relative to C18:0 feeding 
(Rico et al., 2014b). The mechanisms responsible for these elevations in NEFA observed with C16:0 feeding have not been delineated. The rise in circulating NEFA may be caused by the enhanced intake of dietary C16:0; however, we recognize that FA greater than $\mathrm{C} 12$ are converted to their CoA derivatives and re-esterified as TAG once absorbed (Bach and Babayan, 1982). The TAG are subsequently packaged into chylomicrons and readily hydrolyzed by lipoprotein lipase in tissues (Christie et al., 1986). Therefore, the elevations in NEFA observed with PALM may be from dietary origin. Alternatively, an increase in circulating NEFA may reflect greater adipose tissue lipolysis in cows fed C16:0, as suggested by Piantoni et al. (2013); however, we did not observe a change in BCS in PALM-fed cows experiencing positive energy balance. Although not evaluated by Piantoni et al. (2013), we observed an acute decrease in plasma insulin concentrations within the first week of C16:0 feeding; therefore, the anti-lipolytic action of insulin may have been diminished to support short-term NEFA mobilization. In support, we observed a gradual increase in circulating insulin concurrent with a decline in plasma NEFA as cows progressed towards late lactation. Similar to Piantoni et al. (2013), we did not observe a change in plasma TAG in cows fed C16:0; however, we did observe a 51\% increase in circulating total cholesterol by wk 7 . The abomasal infusion of FA of palm oil or the feeding of C16:0-incorporated diets has also been shown to increase the concentration of cholesterol in plasma (Bremmer et al., 1998; van Knegsel et al., 2007; Andersen et al., 2008). Our observed rise in circulating cholesterol with PALM may be due to enhanced formation and lower turnover of low-density lipoproteins, as suggested by Fernandez and West (2005).

The ability of SFA to antagonize insulin action and promote glucose intolerance is well documented in monogastrics (Summers, 2006; Funaki, 2009) however, the ability of SFA to modify insulin action in ruminants is uncertain. In our evaluation of 7-wk C16:0 
supplementation, we did not observe a change in estimated insulin sensitivity or systemic glucose tolerance in PALM-fed cows at wk 3 or 7. Comparably, Piantoni et al. (2013) did not observe a change in systemic insulin sensitivity in mid-lactation cows fed C16:0 at $2 \%$ of diet DM following 3 wk of supplementation, as measured using a GTT as well as an insulin tolerance test. Induction of hyperlipidemia by abomasally infusing tallow or restricting access to feed impairs glucose clearance during a GTT in non-lactating, non-pregnant Holstein cows (Pires et al., 2007); however, augmented NEFA availability during early lactation does not diminish glucose clearance (Saed Samii et al., 2015; Mann et al., 2016). In lactating cows, the inability of SFA to suppress glucose removal following a challenge is likely due to enhanced glucose uptake by the mammary gland (Kronfeld, 1982; Debras et al., 1989), a possible explanation for the similar glucose tolerance measurements observed in our study. Prior to the increase in milk yield, we did observe a decrease in estimated insulin sensitivity exclusively at wk 1 of supplementation, a response that disappeared as the availability of basal plasma insulin increased and plasma NEFA declined with the progression of lactation. The evaluation of RQUICKI across time (i.e. stages of lactation) should be evaluated carefully because this indice of insulin sensitivity does not correspond to direct measurements of insulin sensitivity (GTT or insulin tolerance testing; Saed Samii et al., 2015; Mann et al., 2016), and does not account for NEFA that may be derived from dietary origin. Because the development of FA-induced insulin resistance in lactating dairy cows may be localized to adipose tissue (Zachut et al., 2013), we evaluated changes in circulating NEFA during a series of GTT measurements and observed a progressive decline in glucose-stimulated NEFA disappearance in PALM-fed cows. Because insulin can suppress adipose tissue lipolysis, C16:0-induced adipose tissue insulin resistance may have lessened the anti-lipolytic effect of the glucose challenges. The ability of C16:0 to 
antagonize protein kinase B-dependent insulin signaling in adipose tissue may be mediated by lipid mediators such as ceramide, biomarkers for insulin resistance in insulin resistant humans (Haus et al., 2009) and dairy cattle (Rico et al., 2015). The possible role of C16:0 to mediate adipose tissue insulin resistance and support glucose partitioning to the mammary gland requires further consideration. 


\section{Conclusion}

Optimizing milk yield and components through supplementation of SFA is a current interest of many producers and researchers. Although milk fat and in most cases milk yield are known to increase with $\mathrm{C} 16: 0$ supplementation to lactating cows, the mechanism through which this occurs remains elusive. Therefore, our objective was to evaluate changes in metabolism associated with production responses to long-term feeding of C16:0 to mid-lactation dairy cows. Our results demonstrate that long-term feeding of mid-lactation cows with C16:0 enhances the yield of milk and milk components for a $7 \mathrm{wk}$ duration without suppressing DMI, relative to no added fat supplementation. Gains in milk fat yield during C16:0 supplementation were exclusively due to an increase in C16:0 and C16:1 incorporation into milk fat. The evaluation of metabolic health status revealed acute elevations in circulating NEFA and estimated insulin resistance that preceded beneficial improvements in milk production. Although glucose tolerance was not modified with $\mathrm{C} 16: 0$ feeding, the intake of $\mathrm{C} 16: 0$ for an extended duration enhanced circulating cholesterol and lowered glucose-stimulated NEFA disappearance. Intriguingly, beneficial milk production responses were sustained for two weeks following the removal of C16:0 from the diet. Further studies are required to investigate the effects of C16:0 on localized adipose tissue insulin sensitivity and nutrient partitioning towards the mammary gland. 


\section{TABLES AND FIGURES}

Table 1. Ingredients and nutrient composition (\% of DM unless otherwise noted) of experimental diets supplemented with palmitic acid (PALM; C16:0) and control (no added fat).

\begin{tabular}{lcc}
\hline & \multicolumn{2}{c}{ Treatment } \\
\cline { 2 - 3 } Item & Control & PALM \\
\hline Ingredient (\% DM) & 30.3 & 30.1 \\
Sorghum sudagrass & 29.1 & 28.9 \\
Ground corn & 15.7 & 15.5 \\
Alfalfa haylage & 11.4 & 11.3 \\
Soybean meal & 6.60 & 3.60 \\
Soyhulls & 2.90 & 2.80 \\
Beet pulp pellets & 0.63 & 0.60 \\
Vitamin and mineral premix & 1.60 & 1.60 \\
Protein blend & & 0.94 \\
Sodium bicarbonate & 0.97 & 0.47 \\
Zeolite & 0.48 & 0.29 \\
Limestone & 0.32 & 3.90 \\
C16:0-enriched fat supplement & 3 \\
Nutrient composition & 0.00 & \\
DM, \% & & 59.8 \\
CP, \% DM & 59.6 & 17.3 \\
NDF, \% DM & 17.8 & 31.6 \\
Forage NDF, \% DM & 33.6 & 24.8 \\
Starch, \% DM & 24.8 & 21.6 \\
Ether extract, \% DM & 21.7 & 6.70 \\
Ash, \% DM & 2.80 & 13.1 \\
NE, Mcal/kg DM & 12.6 & 1.50 \\
\hline Vitan & 1.40 &
\end{tabular}

\footnotetext{
${ }^{\mathrm{T}}$ Vitamin-mineral mix contained $14 \% \mathrm{Ca}, 9.5 \% \mathrm{P}, 6.3 \% \mathrm{Mg}, 0.13 \% \mathrm{~K}, 0.78 \% \mathrm{~S}, 4 \% \mathrm{Na}, 17.6 \%$ C, 4282 ppm Fe, 3000 ppm Zn, 590 ppm Cu, 1600 ppm Mn, 62 ppm Se, 53 ppm Co, and 31 ppm I, as well as $507 \mathrm{KIU}$ Vit. A, $69 \mathrm{KIU}$ Vit. D, and 1997.6 KIU Vit. E.

${ }^{2}$ Protein blend contained $30.1 \%$ canola meal solvent, $1.05 \%$ smartamine (Adisseo, Antony, France), $11.1 \%$ corn gluten meal (60\%), $45.7 \%$ soy plus, and $12.1 \%$ blood meal.

${ }^{3}$ Palmitic acid supplement contained 98\% C16:0 (Palmit 98; Global Agri-Trade, Long Beach, CA, USA).
} 
Table 2. Production variables during covariate period.

\begin{tabular}{|c|c|c|c|c|}
\hline \multirow[b]{2}{*}{ Item } & \multicolumn{2}{|c|}{ Treatment $^{1}$} & \multirow[b]{2}{*}{ SEM } & \multirow[b]{2}{*}{$P$-value } \\
\hline & Control & PALM & & \\
\hline Milk Yield, kg/d & 24.5 & 26.5 & 1.50 & 0.39 \\
\hline \multicolumn{5}{|l|}{ Milk solids, $\mathrm{kg} / \mathrm{d}$} \\
\hline Fat & 1.00 & 1.09 & 0.05 & 0.22 \\
\hline Protein & 0.71 & 0.74 & 0.04 & 0.60 \\
\hline Lactose & 1.12 & 0.95 & 0.12 & 0.32 \\
\hline \multicolumn{5}{|l|}{ Milk composition, \% } \\
\hline Fat & 4.06 & 4.15 & 0.19 & 0.75 \\
\hline Protein & 2.90 & 2.81 & 0.11 & 0.52 \\
\hline Lactose & 4.83 & 5.07 & 0.08 & 0.04 \\
\hline $\mathrm{SCC} \times 1000 / \mathrm{mL}$ & 28.9 & 24.9 & 7.50 & 0.70 \\
\hline MUN, mg/dL & 17.9 & 16.5 & 0.91 & 0.21 \\
\hline ECM & 20.5 & 23.7 & 1.90 & 0.27 \\
\hline $3.5 \%$ FCM & 26.9 & 29.3 & 1.50 & 0.25 \\
\hline DMI, $\mathrm{kg} / \mathrm{d}$ & 27.8 & 26.4 & 1.30 & 0.44 \\
\hline $\mathrm{NE}_{\mathrm{L}}$ intake, $\mathrm{Mcal} / \mathrm{d}^{2}$ & 40.6 & 39.3 & 1.50 & 0.53 \\
\hline Feed efficiency $^{3}$ & 0.82 & 0.88 & 0.08 & 0.59 \\
\hline BCS & 2.51 & 2.69 & 0.09 & 0.16 \\
\hline $\mathrm{BW}, \mathrm{kg}$ & 619 & 663 & 18.0 & 0.09 \\
\hline Energy balance, Mcal $/ \mathrm{d}^{4}$ & 20.5 & 10.5 & 2.50 & $<0.01$ \\
\hline
\end{tabular}

Values are presented as LS Means \pm SEM. *, $P<0.05$.

${ }^{1}$ Treatments were either PALM (palmitic acid at $3.9 \%$ of diet DM) or control (no added fat).

${ }^{2} \mathrm{NE}_{\mathrm{L}}$ intake $(\mathrm{Mcal} / \mathrm{d})=\mathrm{DMI}(\mathrm{kg}) \times$ dietary $\mathrm{NE}_{\mathrm{L}}(\mathrm{Mcal} / \mathrm{kg})$.

${ }^{3}$ Feed efficiency $=$ ECM $(\mathrm{kg}) / \mathrm{DMI}(\mathrm{kg})$.

${ }^{4}$ Energy balance $=\mathrm{NE}_{\mathrm{L}}$ intake $-\left(\mathrm{NE}_{\mathrm{M}}+\mathrm{NE}_{\mathrm{L}}\right)$. 
Table 3. Production responses to palmitic acid supplementation.

\begin{tabular}{|c|c|c|c|c|c|c|c|c|c|c|c|c|}
\hline \multirow[b]{3}{*}{ Item } & \multicolumn{6}{|c|}{ Treatment $^{1}$} & & & & \multicolumn{3}{|c|}{$P$-value } \\
\hline & \multicolumn{3}{|c|}{ Week 3} & \multicolumn{3}{|c|}{ Week 7} & \multicolumn{3}{|c|}{ Post-treatment } & \multicolumn{3}{|c|}{ Main Effects ${ }^{2}$} \\
\hline & Control & PALM & SEM & Control & PALM & SEM & Control & PALM & SEM & Treatment & Time & Treatment $\times$ Time \\
\hline Milk Yield, kg/d & 27.7 & $31.6^{*}$ & 1.50 & 25.7 & $30.5 *$ & 1.60 & 25.4 & 28.5 & 1.60 & 0.07 & $<0.01$ & 0.58 \\
\hline $\begin{array}{r}\text { Milk solids, } \mathrm{kg} / \mathrm{d} \\
\text { Fat } \\
\text { Protein } \\
\text { Lactose }\end{array}$ & $\begin{array}{l}1.14 \\
0.94 \\
1.37\end{array}$ & $\begin{array}{l}1.40^{* *} \\
0.98 \\
1.57 \dagger\end{array}$ & $\begin{array}{l}0.05 \\
0.04 \\
0.09\end{array}$ & $\begin{array}{l}1.10 \\
0.87 \\
1.34\end{array}$ & $\begin{array}{l}1.33 * * \\
1.00 * \\
1.51\end{array}$ & $\begin{array}{l}0.06 \\
0.04 \\
0.09\end{array}$ & $\begin{array}{l}1.00 \\
0.87 \\
1.27\end{array}$ & $\begin{array}{l}1.20^{*} \\
1.0^{*} \\
1.43\end{array}$ & $\begin{array}{l}0.06 \\
0.04 \\
0.09\end{array}$ & $\begin{array}{r}<0.01 \\
0.05 \\
0.40\end{array}$ & $\begin{array}{r}<0.01 \\
<0.01 \\
0.01\end{array}$ & $\begin{array}{l}0.46 \\
0.33 \\
0.22\end{array}$ \\
\hline $\begin{array}{r}\text { Milk composition, } \% \\
\text { Fat } \\
\text { Protein } \\
\text { Lactose }\end{array}$ & $\begin{array}{l}4.12 \\
3.24 \\
4.95\end{array}$ & $\begin{array}{l}4.39 \\
3.13 \\
4.96\end{array}$ & $\begin{array}{l}0.19 \\
0.14 \\
0.06\end{array}$ & $\begin{array}{l}4.26 \\
3.44 \\
4.99\end{array}$ & $\begin{array}{l}4.33 \\
3.30 \\
4.97\end{array}$ & $\begin{array}{l}0.20 \\
0.14 \\
0.06\end{array}$ & $\begin{array}{l}4.07 \\
3.52 \\
4.99\end{array}$ & $\begin{array}{l}3.88 \\
3.40 \\
5.00\end{array}$ & $\begin{array}{l}0.19 \\
0.14 \\
0.06\end{array}$ & $\begin{array}{l}0.83 \\
0.65 \\
0.50\end{array}$ & $\begin{array}{r}<0.01 \\
<0.01 \\
0.67\end{array}$ & $\begin{array}{l}0.14 \\
0.24 \\
0.09\end{array}$ \\
\hline $\mathrm{SCC} \times 1000 / \mathrm{mL}$ & 60.4 & 39.6 & 13.7 & 100 & 60.2 & 22.5 & 96.7 & 58.9 & 21.8 & 0.23 & $<0.01$ & 0.23 \\
\hline MUN, mg/dL & 15.4 & 14.2 & 0.76 & 14.4 & 14.2 & 0.77 & 18.5 & 17.6 & 0.77 & 0.30 & $<0.01$ & 0.70 \\
\hline ECM & 29.1 & $33.3 *$ & 1.40 & 27.8 & $32.3 *$ & 1.50 & 25.5 & $31.3 * *$ & 1.50 & $<0.01$ & $<0.01$ & 0.83 \\
\hline $3.5 \% \mathrm{FCM}$ & 30.5 & $36.3 * *$ & 1.40 & 29.4 & $34.7 *$ & 1.50 & 27.4 & $33.6 * *$ & 1.50 & $<0.01$ & $<0.01$ & 0.42 \\
\hline DMI, kg/d & 25.6 & 28.1 & 1.30 & 23.1 & $26.5^{\dagger}$ & 1.30 & 26.3 & 28.0 & 1.30 & 0.15 & 0.18 & 0.23 \\
\hline $\mathrm{NE}_{\mathrm{L}}$ intake, $\mathrm{Mcal} / \mathrm{d}^{3}$ & 35.8 & $42.2 * *$ & 1.40 & 33.9 & $39.8 * *$ & 1.50 & 37.1 & $42.0 *$ & 1.50 & $<0.01$ & 0.19 & 0.04 \\
\hline Feed efficiency ${ }^{4}$ & 1.10 & 1.18 & 0.06 & 1.12 & 1.21 & 0.06 & 0.98 & $1.13 \dagger$ & 0.06 & 0.08 & $<0.01$ & 0.92 \\
\hline $\mathrm{BCS}$ & 2.60 & 2.74 & 0.09 & 2.78 & 2.87 & 0.09 & 2.75 & 2.85 & 0.09 & 0.32 & $<0.01$ & 0.36 \\
\hline $\mathrm{BW}, \mathrm{kg}$ & 642 & 679 & 18.0 & 658 & 691 & 18.2 & 666 & 705 & 18.3 & 0.12 & $<0.01$ & 0.88 \\
\hline Energy balance, $\mathrm{Mcal} / \mathrm{d}^{5}$ & 4.56 & 6.87 & 1.30 & 3.64 & 5.10 & 1.50 & 7.43 & 7.88 & 1.30 & 0.21 & $<0.01$ & 0.01 \\
\hline
\end{tabular}

Values are presented as LS Means \pm SEM for each sampling period.

Significance within wk 3 , wk 7, and post-treatment $P$-values: *, $P<0.05$; **, $P<0.01 ; \dagger, P<0.10$.

${ }^{1}$ Treatments were either PALM (palmitic acid at $3.9 \%$ of diet DM) or control (no added fat).

${ }^{2}$ Main effects across all time points.

${ }^{3} \mathrm{NE}_{\mathrm{L}}$ intake $(\mathrm{Mcal} / \mathrm{d})=\mathrm{DMI}(\mathrm{kg}) \times \operatorname{dietary~} \mathrm{NE}_{\mathrm{L}}(\mathrm{Mcal} / \mathrm{kg})$.

${ }^{4}$ Feed efficiency $=$ ECM $(\mathrm{kg}) / \mathrm{DMI}(\mathrm{kg})$.

${ }^{5}$ Energy balance $=\mathrm{NE}_{\mathrm{L}}$ intake $-\left(\mathrm{NE}_{\mathrm{M}}+\mathrm{NE}_{\mathrm{L}}\right)$. 
Table 4. Milk fatty acid yields (g/d) of cows fed treatment diets.

\begin{tabular}{|c|c|c|c|c|c|c|c|c|c|c|c|c|}
\hline & \multicolumn{6}{|c|}{ Treatment $^{1}$} & & & & \multirow{2}{*}{\multicolumn{3}{|c|}{$\frac{P \text {-value }}{\text { Main Effects }^{2}}$}} \\
\hline & \multicolumn{3}{|c|}{ Week 3} & \multicolumn{3}{|c|}{ Week 7} & \multicolumn{3}{|c|}{ Post-treatment } & & & \\
\hline & Control & PALM & SEM & Control & PALM & SEM & Control & PALM & SEM & Treatment & Time & $\begin{array}{c}\text { Treatment } \times \\
\text { Time }\end{array}$ \\
\hline \multicolumn{13}{|l|}{ Selected individual FA } \\
\hline $4: 0$ & 29.1 & $34.5^{*}$ & 1.60 & 28.9 & $33.9 *$ & 1.70 & 26.5 & 30.4 & 1.60 & 0.01 & 0.02 & 0.57 \\
\hline $6: 0$ & 22.1 & 23.2 & 1.10 & 20.8 & 22.7 & 1.10 & 19.6 & $23.4^{*}$ & 1.10 & 0.04 & 0.01 & 0.04 \\
\hline 8:0 & 13.9 & 13.4 & 0.70 & 13.0 & 13.1 & 0.76 & 12.5 & $15.3 * *$ & 0.76 & 0.16 & $<0.01$ & 0.16 \\
\hline 10:0 & 37.9 & 34.9 & 2.40 & 35.1 & 34.2 & 2.50 & 34.8 & $46.5^{* *}$ & 2.50 & 0.24 & $<0.01$ & 0.24 \\
\hline $12: 0$ & 47.3 & 42.1 & 3.40 & 43.9 & 41.7 & 3.50 & 43.7 & $59.3 * *$ & 3.40 & 0.41 & $<0.01$ & 0.41 \\
\hline 13:0 & 2.32 & 2.02 & 0.16 & 2.29 & 2.11 & 0.16 & 2.16 & $2.75 *$ & 0.17 & 0.66 & $<0.01$ & 0.66 \\
\hline $14: 0$ & 134 & 128 & 7.10 & 125 & 125 & 7.30 & 118 & $146^{* *}$ & 7.30 & 0.20 & $<0.01$ & 0.20 \\
\hline $14: 1$ cis -9 & 11.1 & 11.5 & 0.87 & 11.5 & 11.8 & 0.89 & 9.8 & 12.1 & 0.91 & 0.41 & $<0.01$ & 0.41 \\
\hline $15: 0$ & 10.4 & 9.8 & 0.69 & 10.6 & 10.4 & 0.72 & 10.3 & $13.6 * *$ & 0.72 & 0.31 & $<0.01$ & 0.31 \\
\hline $16: 0$ & 412 & $627 * * *$ & 26.0 & 416 & $607 * * *$ & 27.5 & 352 & 403 & 27.3 & $<0.01$ & $<0.01$ & $<0.01$ \\
\hline $16: 1$ cis-9 & 23.5 & $30.1 * *$ & 1.80 & 22.8 & $30.1 * *$ & 1.90 & 18.9 & 20.8 & 1.80 & 0.08 & $<0.01$ & 0.08 \\
\hline $17: 0$ & 6.27 & 5.57 & 0.33 & 6.34 & 5.81 & 0.35 & 5.88 & $7.57 * * *$ & 0.35 & 0.39 & 0.02 & 0.39 \\
\hline 18:0 & 66.5 & 70.3 & 5.80 & 63.7 & 58.5 & 6.10 & 63.3 & $82.6^{*}$ & 6.01 & 0.22 & $<0.01$ & 0.22 \\
\hline 18:1 trans-4 & 0.08 & $0.07 *$ & 0.01 & 0.05 & 0.05 & 0.01 & 0.07 & $0.08 *$ & 0.01 & 0.56 & $<0.01$ & 0.56 \\
\hline $18: 1$ trans $-6-8$ & 1.42 & 1.46 & 0.08 & 1.25 & 1.27 & 0.09 & 1.27 & $1.66 * * *$ & 0.08 & 0.04 & 0.01 & 0.04 \\
\hline 18:1 trans -9 & 1.25 & 1.12 & 0.05 & 1.05 & 0.99 & 0.05 & 1.05 & $1.30 * * *$ & 0.05 & 0.21 & 0.01 & 0.21 \\
\hline 18:1 trans -10 & 2.05 & 1.97 & 0.09 & 1.49 & 1.49 & 0.10 & 1.74 & 1.99 & 0.10 & 0.34 & $<0.01$ & 0.34 \\
\hline 18:1 trans -11 & 5.08 & 4.13 & 0.35 & 6.26 & 5.26 & 0.37 & 5.79 & $7.38 * * *$ & 0.36 & 0.48 & $<0.01$ & 0.48 \\
\hline 18:1 trans -12 & 1.72 & $1.46 * *$ & 0.09 & 1.31 & 1.10 & 0.10 & 1.46 & $1.88 * * *$ & 0.09 & 0.74 & $<0.01$ & 0.74 \\
\hline $18: 1$ cis -9 & 181 & 190 & 7.15 & 158 & 167 & 7.80 & 151 & $178 * *$ & 7.40 & 0.03 & $<0.01$ & 0.03 \\
\hline $18: 1$ cis-11 & 4.81 & 4.64 & 0.21 & 3.95 & 4.08 & 0.22 & 3.81 & $4.57 * *$ & 0.22 & 0.11 & $<0.01$ & 0.11 \\
\hline $18: 1$ cis -12 & 1.84 & 1.69 & 0.09 & 1.47 & 1.47 & 0.09 & 1.50 & $2.04 * * *$ & 0.09 & 0.12 & $<0.01$ & 0.12 \\
\hline $18: 1$ cis-13 & 0.50 & $0.36^{*}$ & 0.05 & 0.32 & 0.25 & 0.05 & 0.27 & 0.39 & 0.05 & 0.97 & $<0.01$ & 0.97 \\
\hline 18:1 cis- 14, trans-16 & 1.45 & 1.35 & 0.08 & 1.18 & 1.31 & 0.09 & 1.29 & $1.63 * * *$ & 0.08 & 0.22 & $<0.01$ & 0.22 \\
\hline $18: 2$ cis -9, cis -12 & 22.8 & 24.1 & 1.10 & 19.2 & 21.1 & 1.20 & 19.4 & $26.0 * * *$ & 1.20 & $<0.01$ & $<0.01$ & $<0.01$ \\
\hline $18: 3$ cis- 9, cis -12, cis -15 & 2.94 & 2.87 & 0.18 & 3.55 & 3.72 & 0.18 & 3.54 & $4.67 * *$ & 0.19 & 0.03 & $<0.01$ & 0.03 \\
\hline CLA cis-9, trans-11 & 3.23 & $2.48 * *$ & 0.21 & 3.74 & 3.28 & 0.22 & 3.42 & 3.92 & 0.2 & 0.74 & $<0.01$ & 0.74 \\
\hline \multicolumn{13}{|l|}{ Summations ${ }^{3}$} \\
\hline De novo & 279 & 288 & 17.2 & 278 & 281 & 18.1 & 265 & $328 * *$ & 18.0 & 0.16 & $<0.01$ & 0.16 \\
\hline Both & 435 & $657 * * *$ & 26.8 & 439 & $637 * * *$ & 28.3 & 370 & 423 & 28.2 & $<0.01$ & $<0.01$ & $<0.01$ \\
\hline Preformed & 351 & 361 & 15.0 & 321 & 323 & 15.9 & 309 & $376^{* *}$ & 15.8 & 0.01 & 0.03 & 0.01 \\
\hline$\Sigma \mathrm{SFA}$ & 766 & $991 * * *$ & 44.7 & 766 & $953 * * *$ & 47.2 & 690 & $821 *$ & 47.0 & $<0.01$ & $<0.01$ & $<0.01$ \\
\hline$\Sigma$ MUFA-cis & 224 & 239 & 9.50 & 199 & 216 & 10.1 & 186 & $219^{*}$ & 10.1 & 0.01 & $<0.01$ & 0.01 \\
\hline$\Sigma$ PUFA-cis & 25.7 & 27.0 & 1.30 & 22.8 & 24.8 & 1.40 & 22.9 & $30.6 * * *$ & 1.40 & $<0.01$ & $<0.01$ & $<0.01$ \\
\hline$\Sigma$ Unknown & 26.4 & 27.3 & 1.10 & 24.2 & 24.6 & 1.10 & 22.9 & $28.8 * * *$ & 1.10 & 0.01 & 0.17 & 0.01 \\
\hline
\end{tabular}


Values are presented as LS Means \pm SEM.

Significance within wk 3 , wk 7, and post-treatment $P$-values: *, $P<0.05$; **, $P<0.01 ; \dagger, P<0.10$.

${ }^{1}$ Treatments were either PALM (C16:0 at 3.9\% of diet DM) or control (no added fat).

${ }^{2}$ Main effects across all time points.

${ }^{3}$ De novo FA originate from mammary de novo synthesis (<16 carbons), performed FA from extraction from plasma (>16 carbons), and both FA originate from both sources (C16:0 plus cis-9 C16:1). 
Table 5. Milk fatty acid concentration $(\mathrm{g} / 100 \mathrm{~g})$ of cows fed treatment diets.

\begin{tabular}{|c|c|c|c|c|c|c|c|c|c|c|c|c|}
\hline & \multicolumn{6}{|c|}{ Treatment $^{1}$} & & & & \multicolumn{3}{|c|}{$P$-value } \\
\hline & \multicolumn{3}{|c|}{ Week 3} & \multicolumn{3}{|c|}{ Week 7} & \multicolumn{3}{|c|}{ Post-treatment } & \multicolumn{3}{|c|}{ Main Effects $^{2}$} \\
\hline & Control & PALM & SEM & Control & PALM & SEM & Control & PALM & SEM & Treatment & Time & $\begin{array}{c}\text { Treatment } \times \\
\text { Time }\end{array}$ \\
\hline \multicolumn{13}{|l|}{ Selected individual FA } \\
\hline $4: 0$ & 2.73 & 2.64 & 0.07 & 2.79 & 2.66 & 0.07 & 2.78 & 2.67 & 0.07 & 0.24 & $<0.01$ & 0.96 \\
\hline $6: 0$ & 1.99 & $1.77 * * *$ & 0.04 & 1.97 & $1.83 *$ & 0.04 & 2.06 & 2.05 & 0.04 & 0.07 & $<0.01$ & $<0.01$ \\
\hline $8: 0$ & 1.25 & $1.02 * * *$ & 0.03 & 1.21 & $1.06 * * *$ & 0.03 & 1.32 & 1.33 & 0.03 & 0.02 & $<0.01$ & $<0.01$ \\
\hline 10:0 & 3.41 & $2.65 * * *$ & 0.13 & 3.27 & $2.75 * * *$ & 0.13 & 3.66 & 3.83 & 0.13 & 0.09 & $<0.01$ & $<0.01$ \\
\hline $12: 0$ & 4.24 & $3.19 * * *$ & 0.20 & 4.06 & $3.36^{*}$ & 0.20 & 4.57 & 4.88 & 0.20 & 0.17 & $<0.01$ & $<0.01$ \\
\hline 13:0 & 0.19 & $0.15 *$ & 0.01 & 0.18 & 0.16 & 0.01 & 0.22 & 0.24 & 0.01 & 0.55 & $<0.01$ & 0.01 \\
\hline $14: 0$ & 12.0 & $9.8 * * *$ & 0.31 & 11.4 & $10.1 * * *$ & 0.31 & 12.3 & 12.8 & 0.31 & 0.05 & $<0.01$ & $<0.01$ \\
\hline $14: 1$ cis-9 & 1.02 & 0.89 & 0.07 & 0.90 & 0.94 & 0.07 & 1.01 & 1.08 & 0.07 & 0.83 & $<0.01$ & 0.10 \\
\hline $15: 0$ & 0.95 & $0.76 * * *$ & 0.04 & 0.96 & 0.83 & 0.04 & 1.09 & 1.21 & 0.04 & 0.34 & $<0.01$ & $<0.01$ \\
\hline $16: 0$ & 38.2 & $48.0 * * *$ & 1.1 & 40.2 & $48.8 * * *$ & 1.0 & 36.8 & 35.8 & 1.0 & $<0.01$ & $<0.01$ & $<0.01$ \\
\hline $16: 1$ cis -9 & 2.22 & 2.35 & 0.16 & 2.05 & 2.44 & 0.16 & 1.98 & 1.90 & 0.16 & 0.76 & $<0.01$ & 0.01 \\
\hline $17: 0$ & 0.58 & $0.42 * * *$ & 0.01 & 0.60 & $0.46 * * *$ & 0.01 & 0.62 & 0.66 & 0.01 & $<0.01$ & $<0.01$ & $<0.01$ \\
\hline $18: 0$ & 6.33 & 5.28 & 0.43 & 6.29 & $4.68 * *$ & 0.43 & 6.75 & 6.77 & 0.43 & 0.44 & $<0.01$ & $<0.01$ \\
\hline 18:1 trans-4 & 0.01 & $0.01 * *$ & $<0.01$ & $<0.01$ & $<0.01 * * *$ & $<0.01$ & $<0.01$ & 0.01 & $<0.01$ & 0.05 & $<0.01$ & 0.02 \\
\hline $18: 1$ trans $-6-8$ & 0.13 & $0.11 * * *$ & $<0.01$ & 0.12 & $0.10^{*}$ & $<0.01$ & 0.13 & 0.13 & $<0.01$ & 0.27 & $<0.01$ & $<0.01$ \\
\hline 18:1 trans -9 & 0.12 & $0.08 * * *$ & $<0.01$ & 0.10 & $0.08 * * *$ & $<0.01$ & 0.11 & 0.11 & $<0.01$ & $<0.01$ & $<0.01$ & $<0.01$ \\
\hline $18: 1$ trans -10 & 0.19 & $0.15 * * *$ & $<0.01$ & 0.14 & $0.11^{*}$ & $<0.01$ & 0.18 & 0.17 & $<0.01$ & 0.10 & $<0.01$ & $<0.01$ \\
\hline 18:1 trans -11 & 0.48 & $0.31 * * *$ & 0.02 & 0.62 & $0.42 * * *$ & 0.02 & 0.61 & 0.61 & 0.02 & 0.01 & $<0.01$ & $<0.01$ \\
\hline 18:1 trans -12 & 0.16 & $0.10 * * *$ & $<0.01$ & 0.12 & $0.09 * * *$ & $<0.01$ & 0.15 & 0.15 & $<0.01$ & 0.02 & $<0.01$ & $<0.01$ \\
\hline $18: 1$ cis -9 & 16.2 & 14.6 & 0.66 & 15.7 & $13.5^{*}$ & 0.66 & 16.2 & 16.0 & 0.66 & 0.46 & $<0.01$ & $<0.01$ \\
\hline $18: 1$ cis-11 & 0.43 & $0.35 * * *$ & 0.02 & 0.38 & 0.33 & 0.02 & 0.40 & 0.40 & 0.02 & 0.16 & $<0.01$ & 0.01 \\
\hline $18: 1$ cis -12 & 0.18 & $0.12 * * *$ & $<0.01$ & 0.14 & $0.11 * *$ & $<0.01$ & 0.15 & 0.18 & $<0.01$ & 0.20 & $<0.01$ & $<0.01$ \\
\hline $18: 1$ cis-13 & 0.05 & $0.02 * * *$ & $<0.01$ & 0.03 & 0.02 & $<0.01$ & 0.03 & 0.03 & $<0.01$ & 0.19 & $<0.01$ & $<0.01$ \\
\hline 18:1 cis- 14, trans -16 & 0.13 & $0.10 * * *$ & $<0.01$ & 0.11 & $0.09 * *$ & $<0.01$ & 0.13 & 0.13 & $<0.01$ & 0.10 & $<0.01$ & $<0.01$ \\
\hline $18: 2$ cis -9, cis -12 & 2.18 & $1.84 * * *$ & 0.09 & 1.88 & 1.71 & 0.09 & 2.09 & 2.29 & 0.09 & 0.74 & $<0.01$ & $<0.01$ \\
\hline $18: 3$ cis- 9, cis- 12, cis -15 & 0.28 & $0.21 * * *$ & 0.01 & 0.34 & $0.29 *$ & 0.01 & 0.37 & 0.41 & 0.01 & 0.21 & $<0.01$ & $<0.01$ \\
\hline CLA cis-9, trans-11 & 0.29 & $0.19 * * *$ & 0.01 & 0.33 & $0.26 *$ & 0.01 & 0.35 & 0.34 & 0.01 & 0.07 & $<0.01$ & $<0.01$ \\
\hline \multicolumn{13}{|l|}{ Summations ${ }^{3}$} \\
\hline De novo & 26.6 & $21.9 * * *$ & 0.65 & 25.6 & $22.5 * * *$ & 0.65 & 27.8 & 28.7 & 0.65 & 0.03 & $<0.01$ & $<0.01$ \\
\hline Both & 40.4 & $50.3 * * *$ & 1.10 & 42.2 & $51.2 * * *$ & 1.00 & 38.8 & 37.7 & 1.10 & $<0.01$ & $<0.01$ & $<0.01$ \\
\hline Preformed & 32.2 & $27.6^{* * *}$ & 1.00 & 30.6 & $26.1 * * *$ & 1.00 & 33.0 & 33.4 & 1.00 & 0.11 & $<0.01$ & $<0.01$ \\
\hline$\Sigma$ SFA & 72.6 & $75.7 *$ & 0.91 & 73.7 & $76.6^{*}$ & 0.91 & 72.5 & 72.4 & 0.91 & 0.35 & $<0.01$ & $<0.01$ \\
\hline$\Sigma$ MUFA-cis & 20.2 & 18.4 & 0.75 & 19.3 & 17.5 & 0.75 & 20.0 & 19.7 & 0.75 & 0.54 & $<0.01$ & $<0.01$ \\
\hline$\Sigma$ PUFA-cis & 2.46 & $2.06 * * *$ & 0.10 & 2.22 & 2.01 & 0.10 & 2.47 & 2.70 & 0.10 & 0.66 & $<0.01$ & $<0.01$ \\
\hline$\Sigma$ Unknown & 2.51 & $2.09 * * *$ & 0.08 & 2.27 & $1.99 * *$ & 0.08 & 2.47 & 2.57 & 0.08 & 0.07 & $<0.01$ & $<0.01$ \\
\hline
\end{tabular}


Values are presented as LS Means \pm SEM. *,$P<0.05$; **, $P<0.01$; ***, $P<0.001$.

Significance within wk 3, wk 7, and post-treatment $P$-values: *, $P<0.05$; **, $P<0.01 ; \dagger, P<0.10$.

${ }^{1}$ Treatments were either PALM (C16:0 at 3.9\% of diet DM) or control (no added fat).

${ }^{2}$ Main effects across all time points.

${ }^{3}$ De novo FA originate from mammary de novo synthesis (<16 carbons), performed FA from extraction from plasma ( $>16$ carbons), and both FA originate from both sources (C16:0 plus cis-9 C16:1). 
Table 6. Milk fatty acid yield (g/d) and concentration $(\mathrm{g} / 100 \mathrm{~g})$ during covariate period.

\begin{tabular}{|c|c|c|c|c|c|c|c|c|}
\hline \multirow[b]{2}{*}{ Treatment $^{1}$ : } & \multicolumn{3}{|c|}{ Yield } & \multirow[b]{2}{*}{$P$-value } & \multicolumn{3}{|c|}{ Concentration } & \multirow[b]{2}{*}{$P$-value } \\
\hline & Control & PALM & SEM & & Control & PALM & SEM & \\
\hline \multicolumn{9}{|l|}{ Selected individual FA } \\
\hline $4: 0$ & 27.2 & 28.8 & 1.60 & 0.48 & 2.89 & 2.79 & 0.07 & 0.37 \\
\hline $6: 0$ & 18.6 & 20.1 & 1.10 & 0.34 & 1.96 & 1.94 & 0.04 & 0.78 \\
\hline $8: 0$ & 10.8 & 11.9 & 0.72 & 0.27 & 1.13 & 1.15 & 0.03 & 0.74 \\
\hline 10:0 & 27.2 & 30.3 & 2.40 & 0.35 & 2.83 & 2.92 & 0.13 & 0.64 \\
\hline $12: 0$ & 32.0 & 35.5 & 3.40 & 0.46 & 3.34 & 3.41 & 0.20 & 0.80 \\
\hline $13: 0$ & 1.31 & 1.54 & 0.16 & 0.34 & 0.15 & 0.14 & 0.01 & 0.77 \\
\hline $14: 0$ & 99.6 & 111 & 6.90 & 0.23 & 10.5 & 10.7 & 0.31 & 0.55 \\
\hline $14: 1$ cis -9 & 8.39 & 8.80 & 0.87 & 0.74 & 0.89 & 0.84 & 0.07 & 0.61 \\
\hline $15: 0$ & 8.62 & 9.23 & 0.69 & 0.53 & 0.90 & 0.89 & 0.04 & 0.81 \\
\hline $16: 0$ & 359 & 371 & 26.0 & 0.74 & 37.9 & 35.9 & 1.10 & 0.19 \\
\hline $16: 1$ cis -9 & 20.2 & 20.5 & 1.80 & 0.91 & 2.15 & 1.97 & 0.16 & 0.44 \\
\hline $17: 0$ & 5.50 & 6.18 & 0.33 & 0.15 & 0.58 & 0.59 & 0.01 & 0.56 \\
\hline $18: 0$ & 72.8 & 84.7 & 5.80 & 0.15 & 7.29 & 8.29 & 0.43 & 0.11 \\
\hline 18:1 trans-4 & 0.05 & 0.06 & 0.01 & 0.15 & 0.01 & 0.01 & $<0.01$ & 0.54 \\
\hline $18: 1$ trans $-6-8$ & 1.16 & 1.35 & 0.08 & 0.11 & 0.12 & 0.13 & $<0.01$ & 0.37 \\
\hline 18:1 trans -9 & 1.04 & 1.20 & 0.05 & 0.04 & 0.11 & 0.12 & $<0.01$ & 0.46 \\
\hline 18:1 trans -10 & 1.54 & 1.74 & 0.10 & 0.18 & 0.17 & 0.18 & $<0.01$ & 0.36 \\
\hline 18:1 trans -11 & 4.57 & 5.71 & 0.35 & 0.02 & 0.49 & 0.55 & 0.02 & 0.10 \\
\hline 18:1 trans -12 & 1.37 & 1.61 & 0.09 & 0.08 & 0.15 & 0.16 & $<0.01$ & 0.40 \\
\hline $18: 1$ cis -9 & 174 & 194 & 7.30 & 0.06 & 18.0 & 19.9 & 0.69 & 0.05 \\
\hline $18: 1$ cis -11 & 4.53 & 5.02 & 0.21 & 0.11 & 0.47 & 0.50 & 0.02 & 0.24 \\
\hline $18: 1$ cis -12 & 1.48 & 1.69 & 0.09 & 0.11 & 0.16 & 0.18 & $<0.01$ & 0.22 \\
\hline $18: 1$ cis -13 & 0.51 & 0.62 & 0.05 & 0.13 & 0.05 & 0.06 & $<0.01$ & 0.17 \\
\hline 18:1 cis-14, trans -16 & 1.20 & 1.41 & 0.08 & 0.09 & 0.13 & 0.14 & $<0.01$ & 0.33 \\
\hline $18: 2$ cis -9, cis -12 & 17.8 & 21.7 & 1.20 & 0.02 & 1.91 & 2.11 & 0.09 & 0.11 \\
\hline $18: 3$ cis -9, cis -12, cis -15 & 2.63 & 3.01 & 0.18 & 0.14 & 0.29 & 0.29 & 0.01 & 0.67 \\
\hline CLA cis -9, trans -11 & 2.64 & 3.04 & 0.21 & 0.19 & 0.29 & 0.29 & 0.02 & 0.80 \\
\hline \multicolumn{9}{|l|}{ Summations $^{2}$} \\
\hline De novo & 223 & 247 & 17.2 & 0.34 & 23.5 & 23.8 & 0.65 & 0.76 \\
\hline Both & 380 & 392 & 26.8 & 0.74 & 40.1 & 37.9 & 1.10 & 0.16 \\
\hline Preformed & 337 & 391 & 15.0 & 0.01 & 36.3 & 38.2 & 1.00 & 0.21 \\
\hline$\Sigma$ SFA & 663 & 712 & 44.7 & 0.44 & 71.2 & 68.9 & 0.91 & 0.09 \\
\hline$\Sigma$ MUFA-cis & 211 & 243 & 9.50 & 0.02 & 21.8 & 23.7 & 0.76 & 0.08 \\
\hline$\Sigma$ PUFA-cis & 20.4 & 24.7 & 1.30 & 0.02 & 2.19 & 2.41 & 0.10 & 0.14 \\
\hline$\Sigma$ Unknown & 25.2 & 27.5 & 1.10 & 0.13 & 2.69 & 2.68 & 0.08 & 0.89 \\
\hline
\end{tabular}

Values are presented as LS Means \pm SEM.

${ }^{1}$ Treatments were either PALM (C16:0 at 3.9\% of diet DM) or control (no added fat).

${ }^{2}$ De novo FA originate from mammary de novo synthesis ( $<16$ carbons), performed FA from extraction from plasma (>16 carbons), and both FA originate from both sources (C16:0 plus cis9 C16:1). 
Table 7. Area under the curve for glucose and NEFA during glucose tolerance testing.

\begin{tabular}{|c|c|c|c|c|c|c|c|c|}
\hline \multirow[b]{2}{*}{ Time $^{3}$} & \multicolumn{4}{|c|}{ Glucose $^{1}$} & \multicolumn{4}{|c|}{$\mathrm{NEFA}^{2}$} \\
\hline & Control & PALM & SEM & $P$-value & Control & PALM & SEM & $P$-value \\
\hline \multicolumn{9}{|l|}{ Day 0} \\
\hline 60 & 6155 & 6640 & 255 & 0.18 & 3633 & 3752 & 468 & 0.86 \\
\hline 90 & 8290 & 9014 & 353 & 0.16 & 5472 & 5886 & 737 & 0.69 \\
\hline 120 & 10414 & 10953 & 386 & 0.33 & 9272 & 9362 & 1037 & 0.95 \\
\hline 150 & 12223 & 12718 & 457 & 0.44 & 15091 & 13434 & 1702 & 0.50 \\
\hline 180 & 14044 & 14552 & 486 & 0.46 & 21403 & 18250 & 2517 & 0.38 \\
\hline \multicolumn{9}{|l|}{ Day 21} \\
\hline 60 & 6197 & 5992 & 236 & 0.54 & 2523 & 3362 & 454 & 0.20 \\
\hline 90 & 8371 & 8142 & 344 & 0.64 & 4053 & 5281 & 590 & 0.15 \\
\hline 120 & 10226 & 10017 & 367 & 0.68 & 6617 & 8913 & 1013 & 0.12 \\
\hline 150 & 11961 & 11982 & 436 & 0.97 & 9992 & 13037 & 1690 & 0.21 \\
\hline 180 & 13649 & 13557 & 463 & 0.65 & 14041 & 18048 & 2487 & 0.26 \\
\hline \multicolumn{9}{|l|}{ Day 49} \\
\hline 60 & 6153 & 5660 & 242 & 0.16 & 2369 & 3823 & 458 & 0.03 \\
\hline 90 & 8402 & 7628 & 365 & 0.15 & 3770 & 5820 & 615 & 0.02 \\
\hline 120 & 10325 & 9410 & 388 & 0.10 & 6185 & 9508 & 1025 & 0.03 \\
\hline 150 & 12113 & 11744 & 436 & 0.56 & 8617 & 13531 & 1717 & 0.05 \\
\hline 180 & 13925 & 13557 & 477 & 0.58 & 11288 & 18111 & 2533 & 0.06 \\
\hline
\end{tabular}

TAUC for glucose calculated using $(\mathrm{mg} / \mathrm{dL}$ glucose $\times$ min).

${ }^{2}$ AUC for NEFA calculated using ( $\mathrm{mmol} / \mathrm{L}$ NEFA $\times$ min).

${ }^{3}$ Day relative to the start of treatment diets are denoted in bold. Subheadings reflect min relative to infusion of glucose 

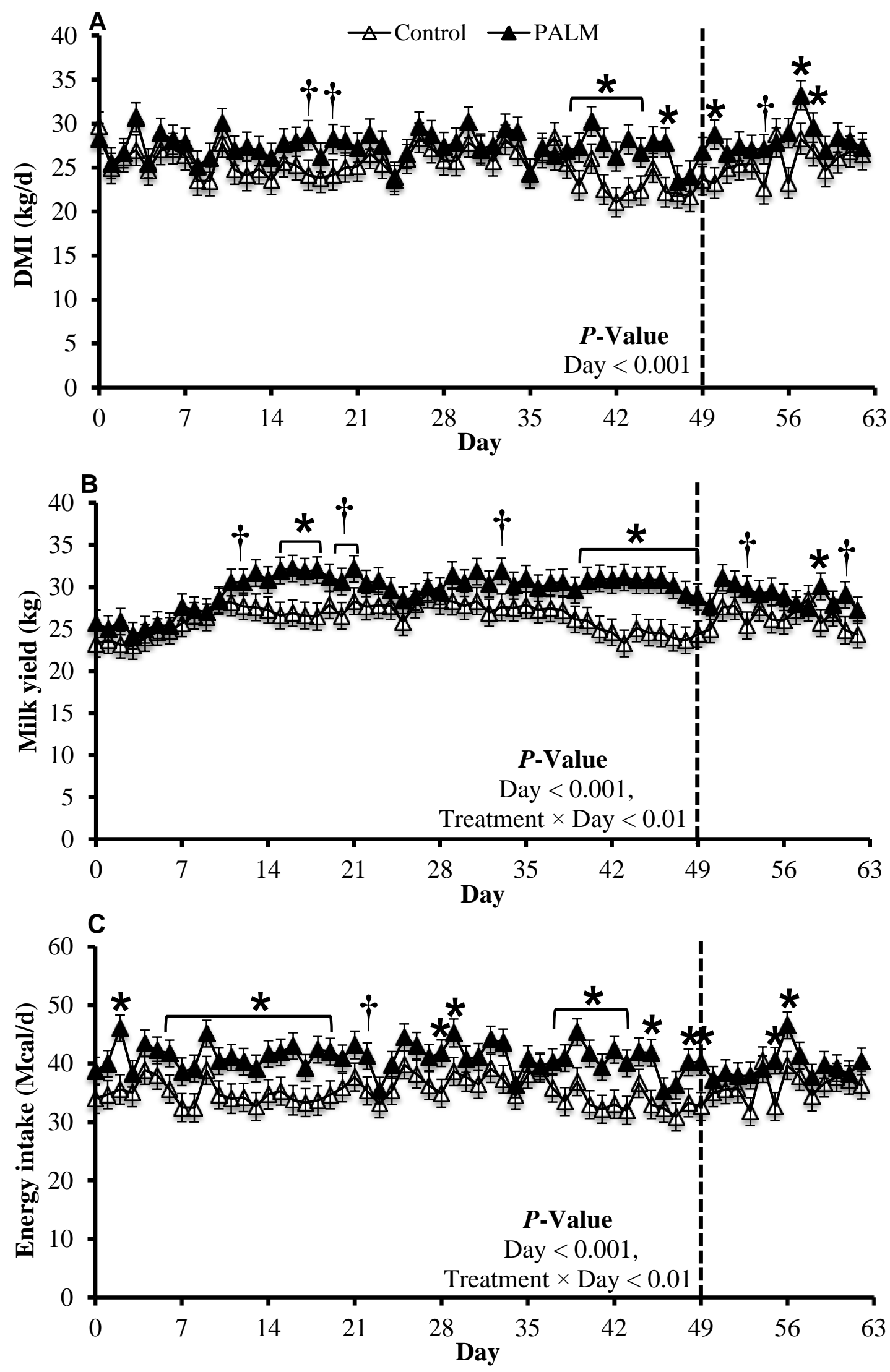
Figure 1. Palmitic acid supplementation increases milk yield and net energy intake.

Continuous evaluation of (A) DMI (kg/d), (B) milk yield (kg/d), and (C) energy intake (Mcal/d) in mid-lactation cows fed PALM or control diets. Data are least squares means and their standard errors. $* P<0.05 ; \dagger P<0.10$. 

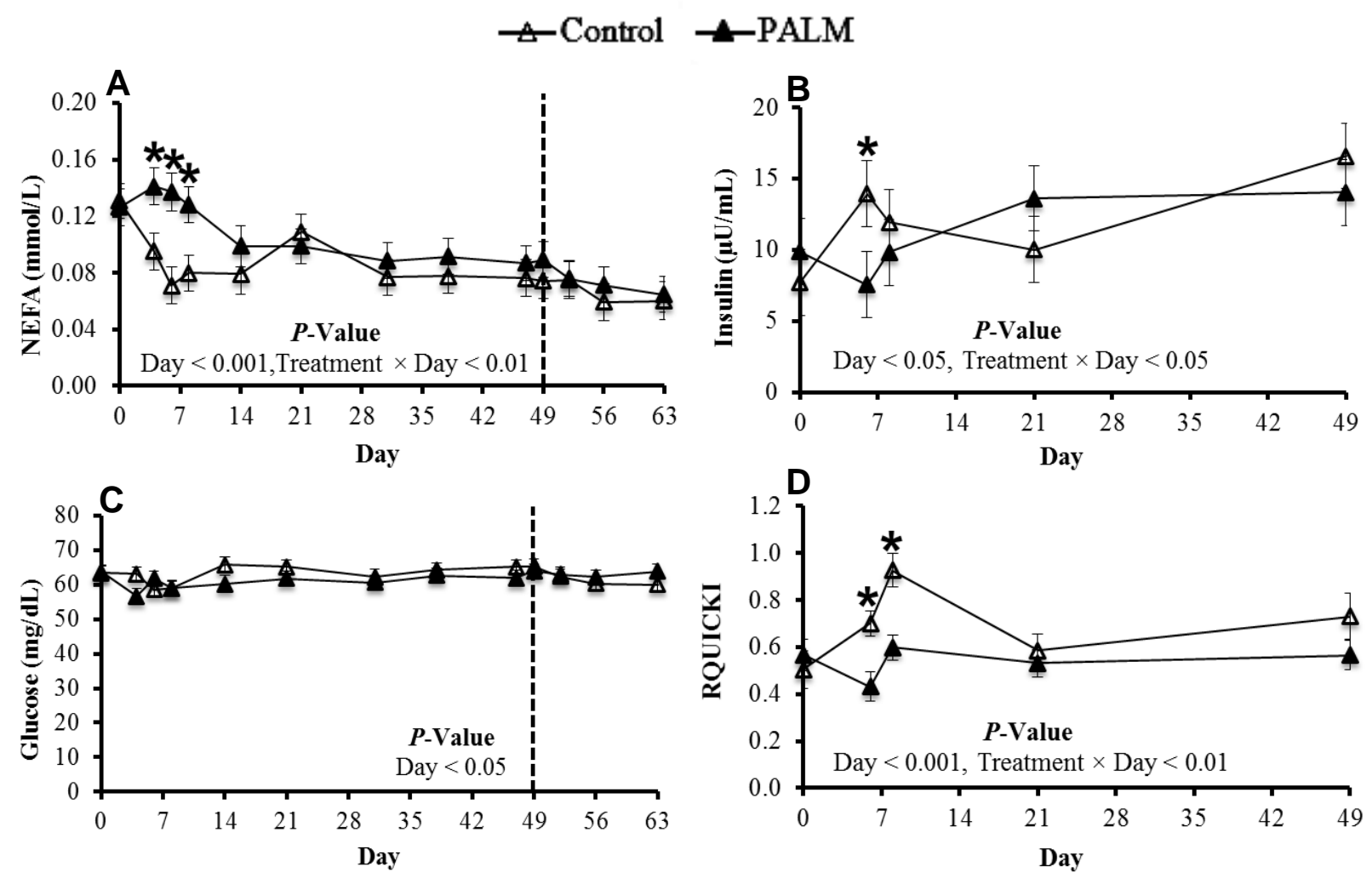

Figure 2. Palmitic acid supplementation acutely increases circulating NEFA and decreases estimated insulin sensitivity.

Plasma concentrations of (A) NEFA, (B) insulin, and (C) glucose of mid-lactation dairy cattle fed control or PALM diets. (D) Estimated insulin sensitivity as measured by the revised quantitative insulin sensitivity check (RQUICKI), where RQUICKI was calculated as follows: $1 /[\log ($ glucose $)+\log ($ insulin $)+\log ($ NEFA $)]$. Lower RQUICKI values are indicative of reduced insulin sensitivity. Data are least squares means and their standard errors. $* P<0.05$. 

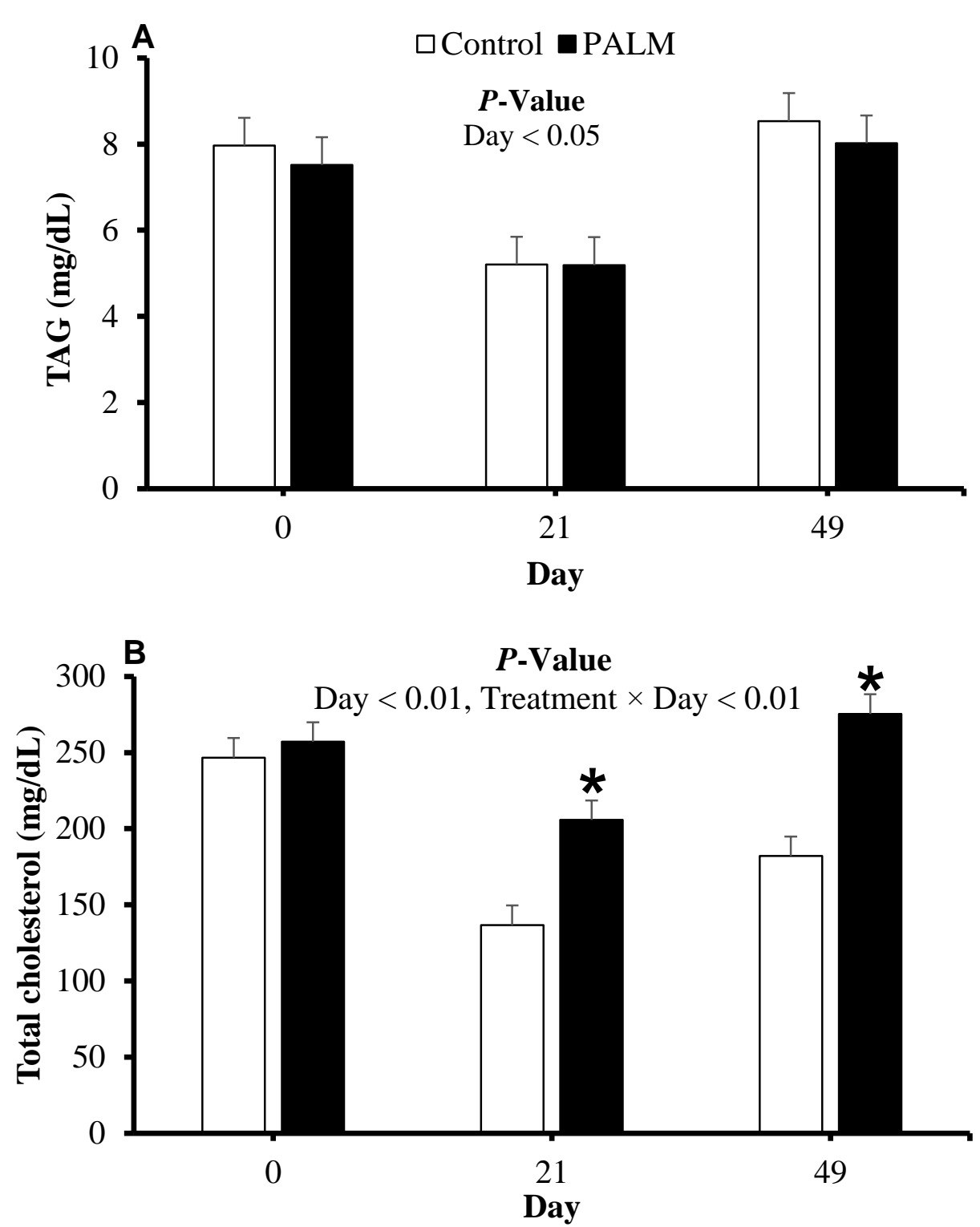

Figure 3. Feeding cows C16:0 increases circulating cholesterol without modifying circulating triacylglycerol .

Plasma concentrations of (A) TAG and (B) total cholesterol in mid-lactation cows fed control or PALM diets. Data are least squares means and their standard errors. ${ }^{*} P<0.05$. 

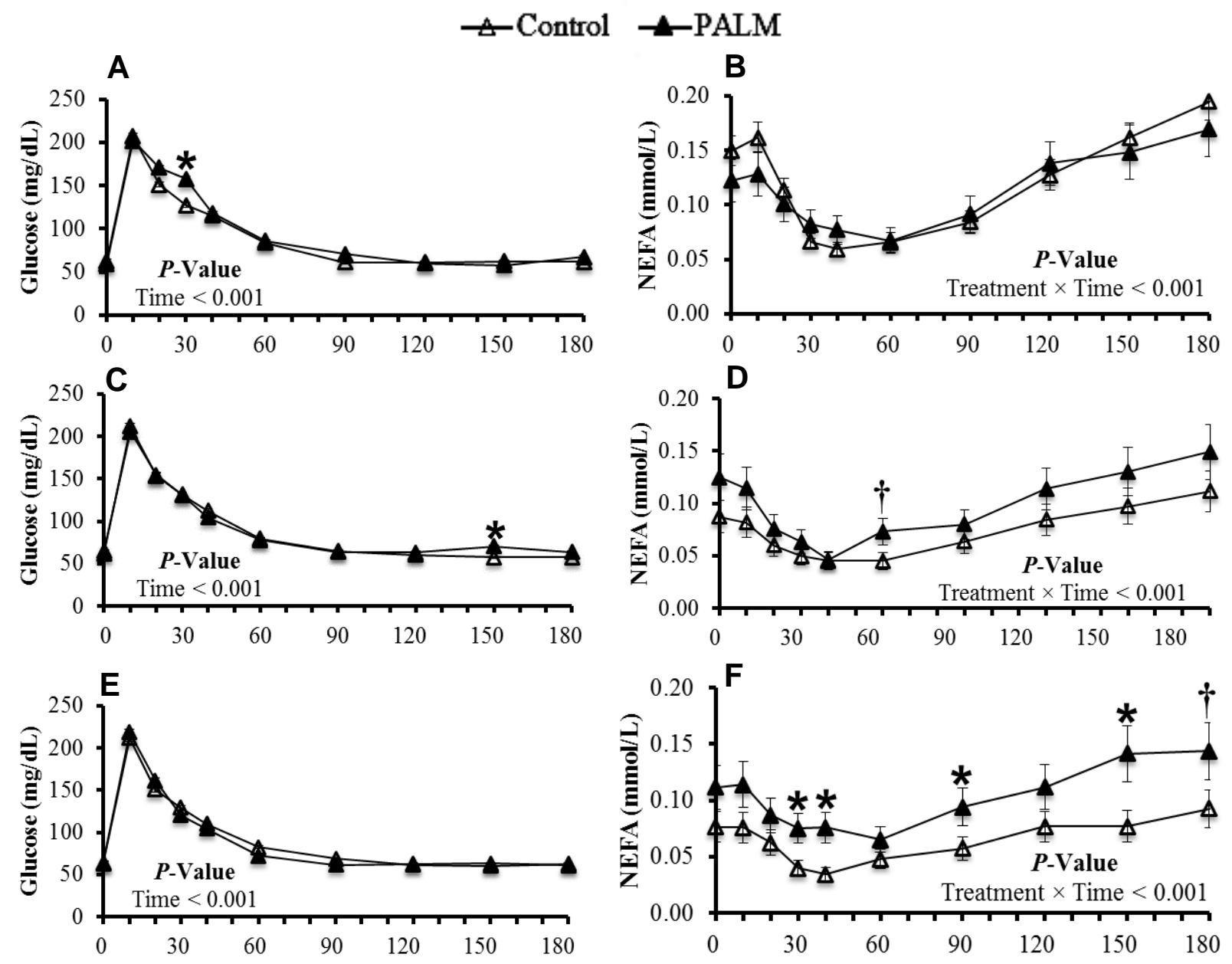

\section{Minute}

Figure 4. Palmitic acid feeding does not modify glucose tolerance but reduces glucose-stimulated NEFA disappearance.

Relative to the initiation of treatment, plasma concentrations of (A, C, and E) glucose and (B, D, and F) NEFA in control and PALM cows challenged with intravenous glucose $(300 \mathrm{mg} / \mathrm{kg}$ of BW) on d 0,21 , and 49 , respectively. Data are least squares means and their standard errors. $* P$ $<0.05 ; \dagger P<0.10$. 


\section{Literature Cited}

Andersen, J. B., C. Ridder, and T. Larsen. 2008. Priming the cow for mobilization in the periparturient period: Effects of supplementing the dry cow with saturated fat or linseed. J. Dairy Sci. 91:1029-1043.

Bach, A. C. and V. K. Babayan. 1982. Medium-chain triglycerides: An update. American Journal of Clinical Nutrition 36:950-962.

Bell, A. W. 1995. Regulation of organic nutrient metabolism during transition from late pregnancy to early lactation. J. Anim. Sci. 73:2804-2819.

Bell, A. W. and D. E. Bauman. 1997. Adaptations of glucose metabolism during pregnancy and lactation. J. Mammary Gland Biol. Neoplasia 2:265-278.

Bremmer, D. R., L. D. Ruppert, J. H. Clark, and J. K. Drackley. 1998. Effects of chain length and unsaturation of fatty acid mixtures infused into the abomasum of lactating dairy cows. J. Dairy Sci. 81:176-188.

Christie, W. W., R. C. Noble, and R. A. Clegg. 1986. The hydrolysis of very low density lipoproteins and chylomicrons of intestinal origin by lipoprotein lipase in ruminants. Lipids 21:252-253.

Contreras, G. A., N. J. O’boyle, T. H. Herdt, and L. M. Sordillo. 2010. Lipomobilization in periparturient dairy cows influences the composition of plasma nonesterified fatty acids and leukocyte phospholipid fatty acids. J. Dairy Sci. 93:2508-2516.

De Koster, J. D. and G. Opsomer. 2013. Insulin resistance in dairy cows. Vet. Clin. N. Am-Food A. 29:299-322.

Debras, E., J. Grizard, E. Aina, S. Tesseraud, C. Champredon, and M. Arnal. 1989. Insulin sensitivity and responsiveness during lactation and dry period in goats. Am. J. Physiol. 256:295-302.

Fernandez, M. and K. West. 2005. Mechanisms by which dietary fatty acids modulate plasma lipids. J. Nutr. 135:2075-2207.

Funaki, M. 2009. Saturated fatty acids and insulin resistance. J. Med. Invest. 56:88-92.

Grummer, R. R. 1991. Effect of feed on the composition of milk fat. J. Dairy Sci. 74:3244-3257.

Hall, M. B. 2009. Determination of starch, including maltooligosaccharides, in animal feeds: Comparison of methods and a method recommended for aoac collaborative study. J. AOAC Int. 92:42-49. 
Haus, J. M., S. R. Kashyap, T. Kasumov, R. Zhang, K. R. Kelly, R. A. Defronzo, and J. P. Kirwan. 2009. Plasma ceramides are elevated in obese subjects with type 2 diabetes and correlate with the severity of insulin resistance. Diabetes. 58:337-343.

Holtenius, P. and K. Holtenius. 2007. A model to estimate insulin sensitivity in dairy cows. Acta Vet. Scand. 49:29.

Kronfeld, D. S. 1982. Major metabolic determinants of milk volume, mammary efficiency, and spontaneous ketosis in dairy cows. J. Dairy Sci. 65:2204-2212.

Lock, A. L., C. L. Preseault, J. E. Rico, K. E. Deland, and M. S. Allen. 2013. Feeding a c16:0enriched fat supplement increased the yield of milk fat and improved conversion of feed to milk. J. Dairy Sci. 96:6650-6659.

Loften, J. R., J. G. Linn, J. K. Drackley, T. C. Jenkins, C. G. Soderholm, and A. F. Kertz. 2014. Invited review: Palmitic and stearic acid metabolism in lactating dairy cows. J. Dairy Sci. 97:4661-4674.

Mann, S., F. a. L. Yepes, M. Duplessis, J. J. Wakshlag, T. R. Overton, B. P. Cummings, and D. V. Nydam. 2016. Dry period plane of energy: Effects on glucose tolerance in transition dairy cows. J. Dairy Sci. 99:701-717.

McNamara, J. P. and J. K. Hillers. 1986. Adaptations in lipid metabolism of bovine adipose tissue in lactogenesis and lactation J. Lipid Res. 27:150-157.

Mosley, S. A., E. E. Mosley, B. Hatch, J. I. Szasz, A. Corato, N. Zacharias, D. Howes, and M. A. Mcguire. 2007. Effect of varying levels of fatty acids from palm oil on feed intake and milk production in holstein cows. J. Dairy Sci. 90:987-993.

NRC. 2001. Nutritional requirements of dairy cattle. 7th rev. ed. Natl. Acad. Sci., Washington, DC.

Piantoni, P., A. L. Lock, and M. S. Allen. 2013. Palmitic acid increased yields of milk and milk fat and nutrient digestibility across production level of lactating cows. J. Dairy Sci. 96:7143-7154.

Pires, J. A., A. H. Souza, and R. R. Grummer. 2007. Induction of hyperlipidemia by intravenous infusion of tallow emulsion causes insulin resistance in holstein cows. J. Dairy Sci. 90:2735-2744.

Rico, D. E., Y. Ying, and K. J. Harvatine. 2014a. Effect of a high-palmitic acid fat supplement on milk production and apparent total-tract digestibility in high- and low-milk yield dairy cows. J. Dairy Sci. 97:3739-3751. 
Rico, J. E., M. S. Allen, and A. L. Lock. 2014b. Compared with stearic acid, palmitic acid increased the yield of milk fat and improved feed efficiency across production level of cows. J. Dairy Sci. 97:1057-1066.

Rico, J. E., V. V. R. Bandaru, J. M. Dorskind, N. J. Haughey, and J. W. McFadden. 2015. Plasma ceramides are elevated in overweight holstein dairy cows experiencing greater lipolysis and insulin resistance during the transition from late pregnancy to early lactation. J. Dairy Sci. 98:7757-7770.

Saed Samii, S., J. E. Rico, A. T. Mathews, C. L. Orndorff, A. D. Davis, and J. W. McFadden. 2015. Comparison of the rquicki estimate of insulin sensitivity with glucose and insulin tolerance in periparturient dairy cows [abstract]. In: ADSA-ASAS Joint Annual Meeting; 2015; July 12-16; Orlando, FL. Abstract nr 65389.

Schoenberg, K. M., R. M. Ehrhardt, and T. R. Overton. 2012. Effects of plane of nutrition and feed deprivation on insulin responses in dairy cattle during late gestation. J. Dairy Sci. 95:670-682.

Steele, W. 1969. The effects of dietary palmitic and stearic acids on milk yield and composition in the cow. J. Dairy Res. 36:369-373.

Storry, J. E., A. J. Hall, and V. W. Johnson. 1973. The effects of increasing amounts of dietary tallow on milk-fat secretion in the cow. J. Dairy Res. 40:293-299.

Summers, S. A. 2006. Ceramides in insulin resistance and lipotoxicity. Prog. Lipid Res. 45:4272.

Ulberth, F. and F. Schrammel. 1995. Accurate quantitation of short-, medium-, and long-chain fatty acid methyl esters by split-injection capillary gas-liquid chromatography. J. Chromatogr. A 704:455-463.

Van Knegsel, A. T. M., H. Van Den Brand, J. Dijkstra, W. M. Van Straalen, R. Jorritsma, S. Tamminga, and B. Kemp. 2007. Effect of glucogenic vs. Lipogenic diets on energy balance, blood metabolites, and reproduction in primiparous and multiparous dairy cows in early lactation. J. Dairy Sci. 90:3397-3409.

Van Soest, P. J., J. B. Robertson, and B. A. Lewis. 1991. Methods for dietary fiber, neutral detergent fiber, and nonstarch polysaccharides in relation to animal nutrition. J. Dairy Sci. 74:3583-3597.

Wang, J. P., D. P. Bu, J. Q. Wang, X. K. Huo, T. J. Guo, H. Y. Wei, L. Y. Zhou, R. R. Rastani, L. H. Baumgard, and F. D. Li. 2010. Effect of saturated fatty acid supplementation on production and metabolism indices in heat-stressed mid-lactation dairy cows. J. Dairy Sci. 93:4121-4127. 
Wildman, E. E., G. M. Jones, P. E. Wagner, and R. L. Boman. 1982. A dairy cow body condition scoring system and its relationship to selected production characteristics. J. Dairy Sci. 65:495-501.

Wright, T. C., J. P. Cant, and B. W. McBride. 2002. Inhibition of fatty acid synthesis in bovine mammary homogenate by palmitic acid is not a detergent effect. J. Dairy Sci. 85:642647.

Zachut, M., H. Honig, S. Striem, Y. Zick, S. Boura-Halfon, and U. Moallem. 2013. Periparturient dairy cows do not exhibit hepatic insulin resistance, yet adipose-specific insulin resistance occurs in cows prone to high weight loss. J. Dairy Sci. 96:5656-5669. 